\title{
Essential functions of Pax5 (BSAP) in pro-B cell development: difference between fetal and adult B lymphopoiesis and reduced $V$-to- $D J$ recombination at the $\operatorname{IgH}$ locus
}

\author{
Stephen L. Nutt, Pavel Urbánek, Antonius Rolink, ${ }^{1}$ and Meinrad Busslinger ${ }^{2}$ \\ Research Institute of Molecular Pathology, A-1030 Vienna, Austria; ${ }^{1}$ Basel Institute for Immunology, CH-4005 \\ Basel, Switzerland
}

The Pax 5 gene coding for the transcription factor BSAP has an essential role in B lymphopoiesis and midbrain development. Here we present a detailed analysis of the B-cell phenotype of Pax 5 mutant mice that revealed a differential dependency of fetal and adult $B$ lymphopoiesis on this transcriptional regulator. B-cell development is arrested in the bone marrow at the early pro-B (pre-BI) cell stage, which is characterized by expression of the early markers c-kit, CD43, $\lambda 5, V_{\text {preB }}$, and HSA and the absence of the later markers CD25 and BP-1. These pre-BI cells fail to express the BSAP target gene $C D 19$ and are capable of long-term proliferation in vitro in the presence of stromal cells and IL-7. B-lymphoid progenitors could not be detected in the fetal liver of Pax 5 mutant embryos. However, Pax5-deficient fetal liver cells gave rise to the development of pre-BI cells in bone marrow on transplantation into lethally irradiated mice. These data indicate different functions of Pax 5 in the distinctive microenvironments of fetal liver and adult bone marrow. As shown by PCR analyses, the pre-BI cells in Pax5-deficient bone marrow have undergone $D_{\mathrm{H}}$-to- $J_{\mathrm{H}}$ rearrangement of the immunoglobulin heavy-chain locus at normal frequency. In contrast, $V_{\mathrm{H}^{-}}$-to- $D_{\mathrm{H}} J_{\mathrm{H}}$ rearrangements were reduced $\sim 50$-fold in Pax5-deficient pre-BI cells, suggesting a role for Pax5 in the developmental pathway controlling $V$-to- $D J$ recombination.

[Key Words: Pax5 inactivation; early B-cell development; fetal and adult B lymphopoiesis; $V_{\mathrm{H}} D_{\mathrm{H}} J_{\mathrm{H}}$ rearrangement; BSAP target genes]

Received August 22, 1996; revised version accepted December 18, 1996.

B lymphocytes develop from hematopoietic stem cells through an orderly process of differentiation that results in antigen-responsive B cells with individual immunoglobulin surface receptors. This developmental process can be dissected into different stages according to the expression of specific cell surface markers and the sequential rearrangement of immunoglobulin heavy $(I g H)$ and light $(\operatorname{Ig} L)$ chain genes (for review, see Rolink and Melchers 1991). In addition, B-cell populations can be distinguished by their growth factor requirements (Hayashi et al. 1990). In the classification scheme of Hardy et al. (1991), sequential stages of mouse B cell development have been divided into seven distinct cell fractions (A-F) based on differential expression of CD43, heat stable antigen (HSA), BP-1, IgM, and IgD (Fig. 1; bottom). Rolink et al. (1994) have instead used the analysis of cell size

${ }^{2}$ Corresponding author.

E-MAIL Busslinger@aimp.una.ac.at; FAX 43-1-798-71-53. and the expression of c-kit, CD25, and the surrogate light chains VpreB and $\lambda 5$ to fractionate B lymphocytes according to their developmental stage (Fig. 1, top). As shown by these studies, the earliest B-cell progenitors in the bone marrow are large cycling cells expressing CD43, c-kit, as well as the surrogate light chain proteins on their surface (Hardy et al. 1991; Karasuyama et al. 1994; Rolink et al. 1994), are in the process of $D_{\mathrm{H}^{-}}$-to- $J_{\mathbf{H}}$ rearrangement of the $\mathrm{IgH}$ locus (Ehlich et al. 1993; Li et al. 1993; ten Boekel et al. 1995) and can be cloned in vitro on stromal cells in the presence of IL-7 (Rolink et al. 1991b). Completion of a productive $V_{\mathrm{H}}$-to- $D_{\mathrm{H}} J_{\mathrm{H}}$ rearrangement results in transient expression of the $\mu$ chain in association with the surrogate light chain proteins on the cell surface (Karasuyama et al. 1990, 1994; Tsubata and Reth 1990; Winkler et al. 1995). Signaling through this pre-B cell receptor transiently down-regulates expression of the recombination activating genes RAG-1 and RAG-2 (Grawunder et al. 1995), promotes allelic exclusion at the $\operatorname{IgH}$ locus (Kitamura and Rajewsky 1992; Löffert et 


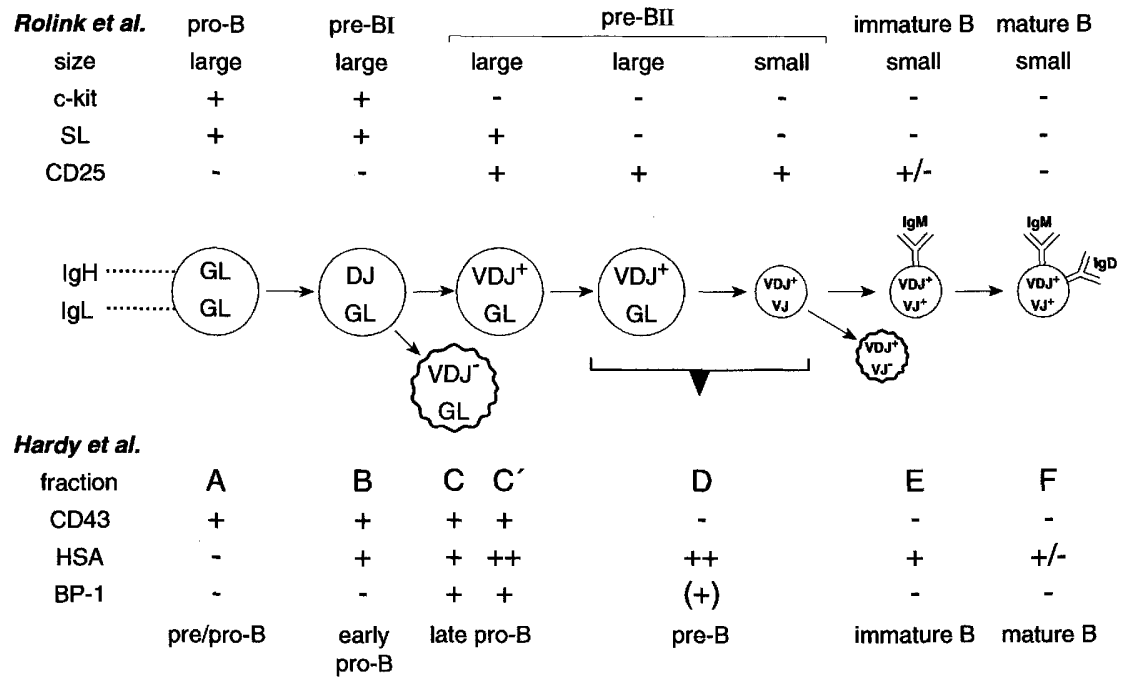

Figure 1. Schematic diagram of murine Bcell development. The different developmental stages of B lymphopoiesis are shown together with their characteristic cell surface markers, which are used for classification according to Rolink et al. (1994) (top) or Hardy et al. (1991) (bottom). The pan-B cell marker B220 is expressed at all stages. The predominant configuration of the immunoglobulin genes at each developmental stage is indicated, as it was determined by ten Boekel et al. (1995) (Rolink's nomenclature) and by Ehilich et al. (1993, 1994) (Hardy's nomenclature). Large and small circles denote proliferating and resting cells, respectively. Cells destined to die are indicated by wavy outlines. As the correlation between the two classification systems is not straightforward in all aspects, the reader is referred to the original literature for details. (GL) Germ line; (SL) surrogate light chain; (IgH) immunoglobulin heavy chain; (IgL) immunoglobulin light chain; (HSA) heat-stable antigen. al. 1996), and induces proliferative cell expansion (Karasuyama et al. 1994; Rolink et al. 1994) as well as differentiation to small pre-B cells (Kitamura et al. 1991, 1992). Following successful $I g L$ ( $\kappa$ or $\lambda$ ) gene rearrangement, immature B cells emerge that synthesize the IgM form of the B-cell receptor and become subjected to selection by antigen. Subsequent expression of homing receptors enables these cells to populate peripheral lymphoid organs where they participate as mature B cells in immunological reactions (Law and Clark 1994).

Several transcription factors have been identified recently that regulate important aspects of B-cell development (for review, see Busslinger and Urbánek 1995; Hagman and Grosschedl 1994). Among them is the B-cellspecific activator protein (BSAP), which is encoded by the Pax5 gene (Adams et al. 1992). This transcription factor is expressed at all stages of B lymphopoiesis except in terminally differentiated plasma cells (Barberis et al. 1990), recognizes DNA via its amino-terminal paired domain (Czerny et al. 1993), and uses a carboxy-terminal regulatory module consisting of activating and inhibitory sequences to control gene transcription (Dörfler and Busslinger 1996). BSAP ( $\operatorname{Pax} 5$ ) has been implicated in the regulation of several B-cell-specific genes primarily based on the identification of BSAP-binding sites in their control regions. Putative BSAP targets are the $I \epsilon$ promoter (Liao et al. 1994) and $3^{\prime}$ enhancers of the $I g H$ and $I g L_{\kappa}$ loci (Singh and Birshtein 1993; Neurath et al. 1994; Roque et al. 1996) as well as the genes coding for the cell surface protein CD19 (Kozmik et al. 1992), the tyrosine kinase Blk (Zwollo and Desiderio 1994), the transcription factor XBP-1 (Reimold et al. 1996), and the surrogate light chains $\lambda 5$ and VpreB1 (Okabe et al. 1992).

Targeted inactivation of the Pax 5 gene in the mouse germ line revealed essential functions of this transcription factor in early B-lymphopoiesis and midbrain devel- opment (Urbánek et al. 1994). Pax5 mutant mice fail to produce small pre-B, B, and plasma cells and therefore lack any immunoglobulin in their senum owing to a complete arrest of B-cell development at an early stage. The bone marrow of these mice generates, however, large $\mathrm{B} 220^{+} \mathrm{CD} 43^{+} \mathrm{B}$ lymphocytes characteristic of early B-cell progenitors (Urbánek et al. 1994; see Fig. 1). Here we have determined the precise developmental stage of the differentiation block by extensive analysis of the expression profile of cell surface proteins and the rearrangement status of immunoglobulin genes in Pax5-deficient $B$ lymphocytes. These experiments revealed a differential requirement for Pax 5 in fetal and adult $B$ lymphopoiesis. Whereas Pax 5 is essential for progression beyond the early pro-B (pre-BI) cell stage in bone marrow, it is required for differentiation of the earliest B-lineage-committed precursor cells in the fetal liver. The pre-BI cells from Pax5-deficient bone marrow could be cultured in vitro on stromal cells in the presence of IL-7 and were shown to lack expression of the BSAP target gene CD19. Moreover, these pre-BI cells have efficiently undergone only $D_{\mathrm{H}^{-}}$-to- $J_{\mathrm{H}}$ rearrangements at the $I g H$ locus which implies a role for Pax5 in the developmental pathway controlling $V_{\mathrm{H}^{-}}$to- $D_{\mathrm{H}} \mathrm{H}_{\mathrm{H}}$ recombination.

\section{Results}

$B$-cell development is arrested at the early pro- $B$ (pre-BI) cell stage in bone marrow of Pax5-deficient mice

Our previous phenotypic analysis of Pax 5 mutant mice demonstrated that the absence of Pax 5 arrests B-cell development in the bone marrow at an early stage corresponding to large $\mathrm{B} 220^{+} \mathrm{CD} 43^{+} \mathrm{B}$ lymphocytes (Urbánek et al. 1994). As indicated in Figure 1, these early B lymphocytes can be subdivided into different developmental 
stages according to the expression of the surface markers HSA, BP-1, c-kit, and CD25 (IL-2R $\alpha$ ). To further characterize the Pax5-dependent differentiation block, we have used antibodies recognizing these stage-specific proteins for flow cytometric analysis of bone marrow cells from Pax5 mutant and control wild-type mice. Because the majority of Pax 5 mutant mice die within 3 weeks after birth (Urbánek et al. 1994), we have analyzed the B-cell compartment (defined by expression of the pan-B-cell marker B220) only up to the age of 2 weeks when these mice are still largely free of disease symptoms. As illustrated in Figure $2 \mathrm{~A}$ (and data not shown), the majority of the $\mathrm{B} 220^{+} \mathrm{CD} 43^{+} \mathrm{B}$ lymphocytes in Pax5-deficient bone marrow express c-kit, HSA, IL-7R, and $\lambda 5$ (3-3.8\% of all cells). The same cells, however, lack CD25, BP-1, and markers of late B-cell differentiation (IgM, IgD, CD21, CD23, CD40) on their cell surface in contrast to wildtype bone marrow cells. This expression profile defines the Pax5-deficient B lymphocytes as early pro-B cells of fraction B in Hardy's nomenclature (Hardy et al. 1991;
Fig. 1), and as pro/pre-BI cells in the classification scheme of Rolink et al. (1994) (Fig. 1). A small subset of Pax5-deficient $\mathrm{B} 220^{+} \mathrm{CD} 43^{+}$cells $(-1 \%$; Fig. $2 \mathrm{~A})$ expresses neither of the early markers c-kit, HSA, and IL$7 \mathrm{R}$ and is therefore likely to correspond to Hardy's fraction A (see Fig. 1), which even includes non-B-lymphoid cells such as progenitors of natural killer cells (Rolink et al. 1996).

The proliferation of Pax5-deficient B lymphocytes was next studied by separating bone marrow cells of Pax 5 mutant mice by fluorescence-activated cell sorting into $\mathrm{B} 220^{+} \mathrm{c}-k_{i t^{+}}$and $\mathrm{B} 220^{+} \mathrm{c}-k i t^{-}$cells. Nuclei were prepared from both cell fractions, and their DNA content was analyzed by flow cytometry (Fig. 2B). Only relatively few $\mathrm{B} 220^{+} \mathrm{c}-\mathrm{kit}^{-}$cells $(8 \%)$ in fraction A proved to be in the cell cycle. In contrast, $40 \%$ of all $\mathrm{B} 220^{+} \mathrm{c}-\mathrm{kit}^{+}$cells in fraction $B$ were in the $S, G_{2}$ or $M$ phase of the cell cycle, which compares favorably with $45 \%$ measured for the $\mathrm{B} 220^{+} \mathrm{c}-\mathrm{kit}^{+}$cell population in wild-type bone marrow (Rolink et al. 1994). We conclude, therefore, that Pax 5 is
Figure 2. B-cell development is blocked at the pre-BI cell stage in bone marrow of Pax5 mutant mice. (A) Flow cytometric analysis. Bone marrow cells from Pax5 mutant $(-1-)$ and wild-type $(+/+)$ mice at the age of 2 weeks were analyzed by flow cytometry using a FITC-conjugated anti-B220/CD45R antibody (RA3-6B2) in combination with either a biotinylated anti-CD43 (S7), anti-HSA (CD24; M1/69), anti-c-kit (ACK4), anti-IL-7R (A7R34), anti-CD25 (IL-2R $\alpha$; 7D4) or anti-BP-1 (6C3) antibody. Biotin-conjugated antibodies were revealed by incubation with PEcoupled streptavidin. The percentages of $\mathrm{B} 22 \mathrm{O}^{+}$cells in each quadrant are indicated. (B) Cell cycle analysis. Bone marrow cells from a 2-week-old Pax5 mutant $(-/-)$ mouse were stained with FITC-conjugated anti-B220 (CD45R) and biotinylated antic-kit antibodies (visualized by PE-conjugated streptavidin) and then separated by fluorescence-activated cell sorting in to the two fractions indicated at left. Nuclei of the sorted cell populations were prepared, stained with ethidium bromide, and analyzed for their DNA content (shown at right). The percentage of cells in the $S, G_{2}$, and $M$ phases of the cell cycle is indicated.
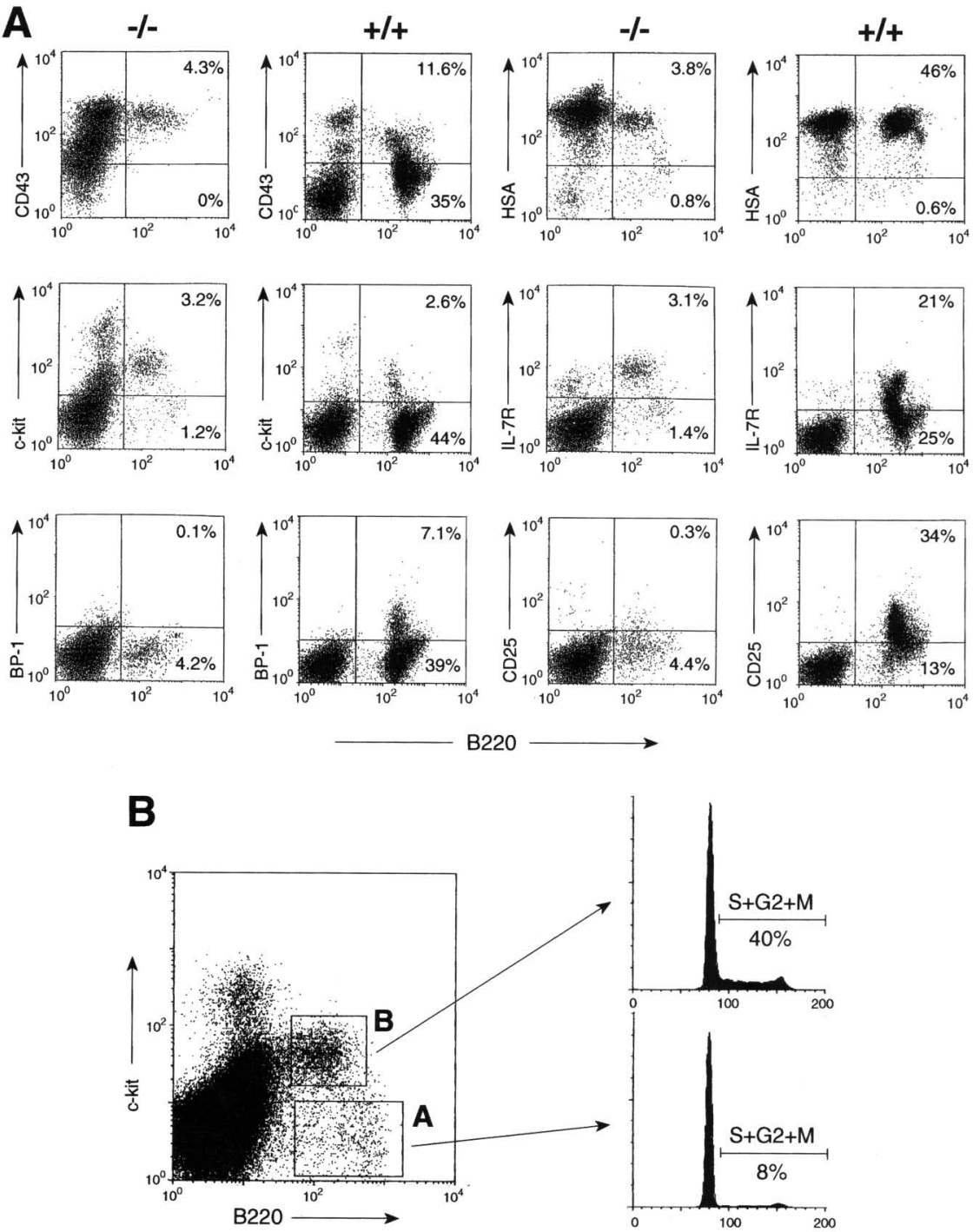
not required for proliferation of early pro-B (pre-BI) cells. However, it is essential for progression of B-cell development beyond this early stage in bone marrow.

\section{Reduced $\mathrm{V}_{H}$-to- $\mathrm{D}_{H} \mathrm{~J}_{H}$ recombination at the $\mathrm{IgH}$ locus in Pax5-deficient pre-BI cells}

The status of immunoglobulin gene rearrangement was next studied in B lymphocytes isolated from bone marrow of Pax5-deficient mice. For this purpose, individual $\mathrm{B} 220^{+} \mathrm{c}-\mathrm{kit}^{+}$cells were first sorted and then analyzed by a recently developed and subsequently modified PCR assay that allows amplification of germ-line and rearranged gene segments from the immunoglobulin loci of a single cell in two steps (Ehlich et al. 1994; ten Boekel et al. 1995). In the first PCR reaction, the $I g H$ and $I g L_{\kappa}$ loci were amplified simultaneously with a mixture of $115^{\prime}$ primers homologous to $V_{\mathrm{H}}, V_{\mathrm{k}}, D_{\mathrm{H}}$ and upstream $J_{\mathrm{H}} 1$ sequences in combination with two $3^{\prime}$ primers located downstream of the $J_{\mathrm{H}} 4$ and $J_{\kappa} 5$ segments. In the second round of amplification, the products of the first PCR were analyzed in separate reactions with primer combi- nations that were specific for each rearrangement event (Ehlich et al. 1994; ten Boekel et al. 1995). As summarized in Figure 3, PCR products were obtained in this manner from $54 \mathrm{~B} 220^{+} \mathrm{c}-k i t^{+}$cells of Pax5-deficient bone marrow. These amplified DNA fragments were characterized according to their size (ten Boekel et al. 1995), and 27 of them were cloned at random followed by DNA sequencing (Fig. 3B). This analysis indicated that 9 alleles of the IgH locus were still in germ-line configuration, whereas 65 alleles underwent $D_{\mathrm{H}} J_{\mathrm{H}}$ rearrangement (Fig. $3 \mathrm{~A})$. $D_{\mathrm{H}^{-}}$-to- $J_{\mathrm{H}}$ joining is usually imprecise at the recombination breakpoint because of deletion of $D_{\mathrm{H}}$ and $J_{\mathrm{H}}$ sequences as well as insertion of template-independent nucleotides (N and P) (Desiderio et al. 1984; Lafaille et al. 1989). The $D_{\mathrm{H}} J_{\mathbf{H}}$ joints in Pax5-deficient B lymphocytes were normal in both of these aspects, as shown by DNA sequence analysis (Fig. 3B). Importantly, neither $V_{\mathrm{H}} D_{\mathrm{H}} J_{\mathrm{H}}$ nor $V_{\mathrm{K}} J_{\mathrm{K}}$ rearrangements could be detected in our sample of Pax5-deficient pre-BI cells (Fig. 3A). This finding was not an artifact of the $V_{\mathrm{H}^{-}}$-specific primers used, as they were able to amplify efficiently $V_{\mathrm{H}} D_{\mathrm{H}} J_{\mathrm{H}}$-rearranged alleles from individual pre-BII cells of wild-type mice

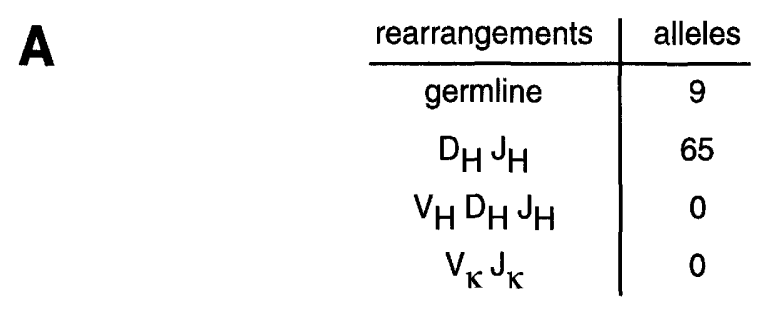

B

\begin{tabular}{|c|c|c|c|c|c|}
\hline \multicolumn{3}{|c|}{ DH JH junctions } & \multicolumn{3}{|c|}{ type } \\
\hline $\mathbf{D}_{\mathrm{H}}$ & $\mathbf{P}, \mathbf{N}$ & $J_{H}$ & $\mathbf{D}_{\mathbf{H}}$ & $J_{H}$ & $\mathbf{R F}$ \\
\hline TCT ATG ATG GCT AC & G TGA & TAC TAT GCT ATG GAC TAC TGG & Dsp2.9 & $\mathrm{J} 4$ & II* \\
\hline TC TAC TAT GAT AAC GAC & CCTAC & C TAT GCT ATG GAC TAC TGG & Dsp2.2 & $\mathrm{J} 4$ & 1 \\
\hline T CTA CTA TGA TTA CGAC & GC & TAC TAT GCT ATG GAC TAC TGG & Dsp2.2 & J4 & III \\
\hline T CTA CTA TGG TAACTA & $A G G$ & GCT TAC TGG & Dsp2.1/2.5 & J3 & III \\
\hline TC TAC TAT GG & G AAA AGG G & AC TAT GCT ATG GAC TAC TGG & Dsp2 & $\mathrm{J} 4$ & 1 \\
\hline T CTA CTA TGA TTG CGAC & $\mathrm{GC}$ & TAC TAT GCT ATG GAC TAC TGG & Dsp2.2 & $\mathrm{J} 4$ & III \\
\hline C CTA CTA TAG TAAC & $\mathrm{cc}$ & TAC TGG & Dsp2.X & $\mathrm{J} 3$ & III \\
\hline CCT AGT ATG GTAACT AC & G TC & G TTT GCT TAC TGG & Dsp2.8 & J3 & ॥ \\
\hline TC TAC TAT AGG AAC GAC & TAT & TAC TAT GCT ATG GAC TAC TGG & Dsp2.10 & $\sqrt{4}$ & 1 \\
\hline T TTA TTA CTA CGG TAG TAG C & $\mathrm{CCG}$ & TT GCT TAC TGG & Dfl16.1 & $\sqrt{3}$ & III \\
\hline CC TAC TAT AGG TAC GAC & GGG GC & G CCT GGT TTG CTT TAC TGG & Dsp2.11 & $\sqrt{3}$ & 1 \\
\hline CC TAC TAT & $\pi$ & G CCT GGT TTG CTT TAC TGG & Dsp2 & $\sqrt{3}$ & 1 \\
\hline TTT ATT ACT ACG GTA GTA GCT AC & $\mathrm{CC}$ & AC TAT GCT ATG GAC TAC TGG & Dfl16.1 & $\mathrm{J} 4$ & $\|$ \\
\hline TT TAT TAC TAC GGT AGT AGC & CCC GGG GC & C TAT GCT ATG GAC TAC TGG & Dfl16.1 & J4 & 1 \\
\hline TIT ATT ACT ACG GTA GTA & TCC CG & C TGG TTT GCT TAC TGG & Dfl16.1 & J3 & II \\
\hline C CTA CTA CTA TAG TAAC & $\mathrm{CC}$ & TAC TAT GCT ATG GAC TAC TGG & Dsp2.X & J4 & III \\
\hline TC TAC TAT GGT AAC TAC & GTA TAT & TAC TAT GCT ATG GAC TAC TGG & Dsp2.1/2.5 & j4 & 1 \\
\hline T CTA TGA TGG TTA CTA C & $\pi$ & TAC TAT GCT ATG GAC TAC TGG & Dsp2.9 & $\mathrm{J} 4$ & III \\
\hline TCT ACT ATG G & $A G G$ & TG GAC TAC TGG & Dsp2 & $\mathrm{J} 4$ & $\|$ \\
\hline T CTA CTA TGA TTA CGA C & GA GGG GGG A & CC TGG TIT GCT TAC TGG & Dsp2.2 & J3 & III \\
\hline CC TAC TAT AGT AAC TA & G CAT & TAC TAT GCT ATG GAC TAC TGG & Dsp2.X & J4 & 1 \\
\hline C CTA GTA TGG T & $\mathbf{T}$ & C TIT GAC TAC TGG & Dsp2.8 & J2 & III \\
\hline TCT ACT ATG ATT ACG AC & G GG & C TTT GAC TAC TGG & Dsp2.2 & J2 & $\|$ \\
\hline TC TAC TAT GGT AAC TAC & TाT & TAC TGG TAC TTC GAT GTC TGG & Dsp2.1/2.5 & J1 & 1 \\
\hline CCT ACT ATA GGT ACG AC & G ACG & GCT ATG GAC TAC TGG & Dsp2.11 & J4 & $\|$ \\
\hline CCT ACT ATA GT & $\mathrm{C}$ & GCT ATG GAC TAC TGG & Dsp2.X & $\mathrm{J} 4$ & $\|$ \\
\hline TCT ACT ATG ATT ACG AC & G GGA CGG TAT & TATG GAC TAC TGG & Dsp2.2 & $\mathrm{J4}$ & $\|$ \\
\hline
\end{tabular}

Figure 3. Status of immunoglobulin gene rearrangement in bone marrow pre-BI cells of Pax5-deficient mice. (A) Summary of the PCR analysis of immunoglobulin gene rearrangements in single cells. $\mathrm{B} 220^{+} \mathrm{c}-\mathrm{kit}^{+}$ cells from bone marrow of 2 -week-old $\operatorname{Pax} 5(-/-)$ mice were stained and sorted as described in Fig. 2B. In total, 88 individual cells were subjected to PCR analysis according to Ehlich et al. (1994) with the modifications described by ten Boekel et al. (1995). Both $\mathrm{IgH}$ alleles were detected in 20 cases $(23 \%)$, a single PCR band was observed in 34 samples $(38.5 \%)$ and no amplification was obtained in 34 cases $(38.5 \%)$. Numbers refer to the occurrence of the different immunoglobulin gene rearrangements. $(B)$ Junctional sequences of the $D_{\mathrm{H}} /{ }_{\mathrm{H}}$-rearranged $\mathrm{IgH}$ genes in Pax5-deficient $\mathrm{B}_{2} 2 \mathrm{O}^{+} \mathrm{c}-\mathrm{kit}^{+}$cells. DNA fragments amplified from $27 D_{\mathrm{H}} J_{\mathrm{H}}$-rearranged alleles were cloned and sequenced. The type of $J_{\mathrm{H}}$ and $D_{\mathrm{H}}$ segments used as well as the $D_{\mathrm{H}}$ reading frame $(R F$; conventionally standardized relative to $J_{\mathrm{H}}$ ) were determined as described (Ichihara et al. 1989; Chang et al. 1992). Template-independent nucleotides $(\mathrm{N})$, which are inserted by terminal deoxynucleotidyl transferase (Alt and Baltimore 1982; Desiderio et al. 1984), and short palindromic sequences $(\mathrm{P})$, which are complementary to the ends of the recombining gene segments (Lafaille et al. 1989), are listed. $\mathrm{N}$ sequence insertion generated a stop codon in reading frame II of one $D_{\mathrm{H}} \mathrm{H}_{\mathrm{H}^{-}}$ rearranged allele (indicated by asterisk), therefore preventing translation of the $\mathrm{D} \mu$ protein. 
(data not shown). The failure to detect $V_{\mathrm{H}} D_{\mathrm{H}} /_{\mathrm{H}}$ rearrangements in Pax5-deficient pre-BI cells is therefore significant and contrasts with results obtained in previous single-cell PCR analyses of wild-type bone marrow cells. Ehlich et al. (1994) found that the early pro-B cells in Hardy's fraction B contain $24 \%(9 / 38)$ of all analyzed $I g H$ alleles in the $V_{\mathrm{H}} D_{\mathrm{H}} J_{\mathrm{H}}$-rearranged configuration. Likewise, ten Boekel et al. (1995) observed $V_{\mathrm{H}} D_{\mathrm{H}} J_{\mathrm{H}}$ joining in $13 \%(4 / 30)$ of the $I g H$ alleles analyzed from B220 $0^{+}$-kit ${ }^{+}$ pre-BI cells. Based on these two studies, we would have expected to identify $10-18 \quad V_{\mathrm{H}} D_{\mathrm{H}} J_{\mathrm{H}}$ rearrangements among the $74 \mathrm{IgH}$ alleles analyzed from Pax5-deficient pre-BI cells. The absence of any $V_{\mathrm{H}} D_{\mathrm{H}} J_{\mathrm{H}}$-rearranged allele strongly suggests that the incidence of $V_{\mathrm{H}}$-to- $D_{\mathrm{H}} J_{\mathrm{H}}$ rearrangement is at least 10 -fold reduced in the absence of Pax5.

To verify the significance of this PCR result, we have sorted $\mathrm{B} 22 \mathrm{O}^{+} \mathrm{c}-\mathrm{kit}^{+}$cells from the bone marrow of wildtype and Pax 5 mutant mice and used a pool of 10,000 cells rather than individual $B$ lymphocytes as starting material for PCR amplification by the two-step protocol described above. As expected, $I g H$ gene sequences could be amplified readily in germ-line and $D_{\mathrm{H}} J_{\mathrm{H}}$-rearranged configurations from both wild-type and three Pax $5 \mathrm{mu}$ tant mice (Fig. 4A). In contrast, the pre-BI cells of only one of the three mutant mice gave rise to an amplification product with $V_{\mathrm{H}} \mathrm{J} 558$-specific primers. Therefore, $V_{\mathrm{H}} D_{\mathrm{H}} J_{\mathrm{H}}$ rearrangements involving members of the prominent $V_{\mathrm{H}} 7558$ gene family were present in $\mathrm{Pax} 5 \mathrm{mu}$ tant mice just at the detection limit of our PCR assay (Fig. 4A). Similar results were also obtained by PCR amplification with primers specific for the $V_{\mathrm{H}} 7183$ and $V_{\mathrm{H}} \mathrm{Q} 52$ gene families (data not shown). As $70-80 \%$ of all $V_{\mathrm{H}} D_{\mathrm{H}} J_{\mathrm{H}}$ rearrangements normally occur within these three $V_{\mathrm{H}}$ gene families (Yancopoulos et al. 1988; Malynn et al. 1990), we conclude that $V_{\mathrm{H}} D_{\mathrm{H}} J_{\mathrm{H}}$ rearrangements are rare in pre-BI cells of Pax5 mutant mice.

The frequency of $V_{\mathrm{H}} D_{\mathrm{H}} \mathrm{H}_{\mathrm{H}}$ rearrangements in Pax5-deficient B lymphocytes was next estimated by a quantitative PCR assay. For this experiment we have sorted $\mathrm{CD} 43^{+} \mathrm{B} 220^{+}$cells, as this population contains both c$\mathrm{kit}^{+}$and $\mathrm{c}-\mathrm{kit}^{-}$cells and therefore includes all B lymphocytes of Pax5-deficient bone marrow (Fig. 2A). Increasing numbers of $\mathrm{B} 220^{+} \mathrm{CD} 43^{+}$cells from Pax 5 mutant and wild-type mice were analyzed by 30 cycles of PCR amplification with $V_{\mathrm{H}} / 558$-specific primers. As shown in Figure $4 \mathrm{~B}$, only few $V_{\mathrm{H}} D_{\mathrm{H}} J_{\mathrm{H}}$ rearrangements could be amplified from $10,000 \mathrm{~B} 220^{+} \mathrm{CD} 43^{+}$cells of Pax5 mutant mice in marked contrast with the situation observed with wild-type littermates. The amplified $V_{\mathrm{H}} D_{\mathrm{H}} J_{\mathrm{H}}$ fragments were quantitated by normalization to a PCR product from the $\mathrm{C} \mu$ region of the $I g H$ locus that was used as a control for the number of genomes analyzed. As indicated by this quantitation, the incidence of $V_{\mathrm{H}} D_{\mathrm{H}} /_{\mathrm{H}}$ rearrangements in $\mathrm{B}_{2} 2 \mathrm{O}^{+} \mathrm{CD} 43^{+}$cells was 50 - to 70 -fold reduced in Pax5 mutant mice compared with wild-type animals. The combined results of all PCR experiments demonstrate therefore that the absence of Pax 5 results in a low frequency of $V_{\mathrm{H}}$-to- $D_{\mathrm{H}} J_{\mathrm{H}}$ rearrangements at the pre-BI cell stage.
A

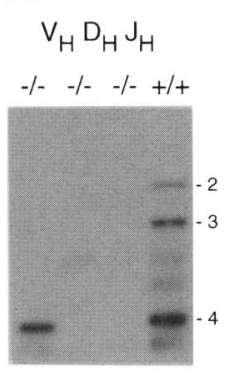

B

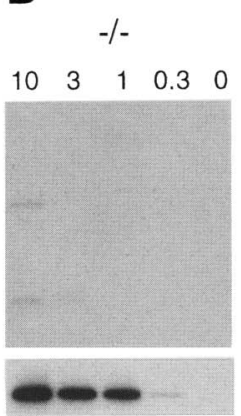

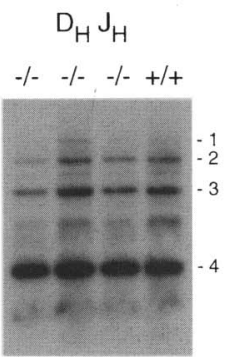

$-1-$

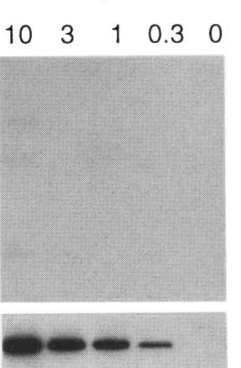

germline

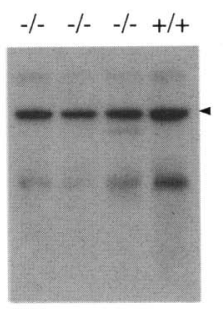

$+/+$
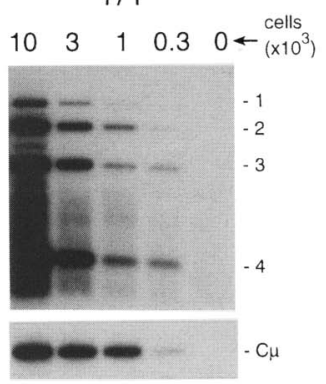

Figure 4. Reduced $V$-to- $D J$ recombination at the $I g H$ locus in pre-BI cells of Pax5-deficient mice. (A) PCR analysis of pre-BI cells. $\mathrm{B} 22 \mathrm{O}^{+} \mathrm{c}-\mathrm{kit}{ }^{+}$cells were sorted from the bone marrow of three Pax 5 mutant mice $(-/-)$ and one wild-type littermate $|+|+\mid$ at the age of 2 weeks. Ten thousand of these pre-BI cells were subjected to the same two-step PCR amplification protocol that was used for the analysis of $I g H$ gene rearrangements in single cells (Fig. 3; Materials and Methods). PCR amplification products were detected by Southern blot hybridization with a 120 -bp probe containing DNA sequences $3^{\prime}$ of the $\int_{\mathrm{H}^{4}} 4$ segment. $V_{\mathrm{H}} D_{\mathrm{H}} J_{\mathrm{H}}$ rearrangements involving members of the prominent $V_{\mathrm{H}} / 558$ gene family were amplified with a $V_{\mathrm{H}} / 558$-specific primer pair (Ehlich et al. 1994). Numbers at right refer to the $J_{\mathrm{H}}$ segments used for rearrangement; the arrow points to the position of the amplified germ-line fragment. Cloning and sequencing of the only $V_{\mathrm{H}} D_{\mathrm{H}} J_{\mathrm{H}}$ fragment amplified from $P a x 5(-/-)$ pre-BI cells indicated that it consisted of just one unique sequence, therefore corresponding to a single $V_{\mathrm{H}}$-to- $D_{\mathrm{H}} J_{\mathrm{H}}$ rearrangement event. (B) Quantitation of $V_{\mathrm{H}} D_{\mathrm{H}} / \mathrm{H}$ rearrangements in $\mathrm{B} 220^{+} \mathrm{CD} 43^{+}$cells. Increasing numbers $(300$ to 10,000$)$ of $\mathrm{B} 220^{+} \mathrm{CD} 43^{+}$cells, which were sorted from the bone marrow of two mutant mice $(-/-)$ and one wild-type littermate $(+\mid+)$, were analyzed by 30 cycles of PCR amplification with a $V_{\mathrm{H}} / 558$-specific primer pair, and the four different $V_{\mathrm{H}} D_{\mathrm{H}} J_{\mathrm{H}}$ fragments were detected by Southern blot analysis (see Materials and Methods). The autoradiographs shown were exposed for the same time period. A DNA segment from the $\mathrm{C} \mu$ region of the $\operatorname{IgH}$ locus was amplified in parallel to control for the number of genomes analyzed. Quantitation of the $V_{\mathrm{H}} D_{\mathrm{H}} J_{\mathrm{H}}$ signals by PhosphorImager analysis and normalization to the $\mathrm{C} \mu$ signal indicated a 50 to 70 -fold lower incidence of $V_{\mathrm{H}} D_{\mathrm{H}} \mathrm{H}_{\mathrm{H}}$ rearrangements in the pax 5 mutant cells compared with the wild-type cells.

Long-term proliferation potential of Pax5-deficient pre-BI cells in vitro

The growth factor requirement of B-lymphoid cells provides yet a third criterion to define their developmental 
stage. For instance, pre-BI cells from the bone marrow of wild-type mice can be cultured in vitro on stromal cells in the presence of IL-7 (Rolink et al. 1991b). The long-term proliferation capacity of these cells is known to be critically dependent on the expression of c-kit and IL-7R (Rolink et al. 1991a; Sudo et al. 1993), both of which are expressed on Pax5-deficient B lymphocytes (Fig. 2A). To examine the in vitro proliferation potential of these cells, we have used fluorescence-activated cell sorting to seed individual $\mathrm{B}^{2} 2 \mathrm{O}^{+} \mathrm{c}-\mathrm{kit}^{+}$cells from the bone marrow of Pax 5 mutant mice into single wells containing stromal ST2 cells and IL-7 medium. Under these conditions, one out of five cells grew into a colony that could be further propagated as a cell line in culture (data not shown). The same cloning frequency $(1 / 5)$ was determined previously for $\mathrm{B} 220^{+} \mathrm{c}-\mathrm{kit}^{+}$cells isolated from the bone marrow of wild-type mice (Rolink et al. 1993). Therefore, the absence of Pax 5 does not affect the clonability of bone marrow pre-BI cells.

The cell surface phenotype of in vitro propagated preBI cells lacking Pax5 was next compared, by flow cytometric analysis, with that of wild-type pre-BI cells. As shown in Figure 5, both cell populations expressed similar levels of B220, c-kit, CD43, IL-7R, and VpreB, but differed in the synthesis of the BP-1 and CD19 proteins, which were absent from Pax5-deficient pre-BI cells. These results combined with the in vivo data of Figure $2 \mathrm{~A}$ indicate that, at this level of analysis, the Pax5-defi- cient pre-BI cells have apparently not altered their phenotype on in vitro culturing.

\section{B-cell-specific gene expression in Pax5-deficient pre-BI cells}

BSAP (Pax5) is only one of several transcription factors that have essential roles in early B-cell development (for review, see Busslinger and Urbánek 1995). The availability of homogeneous pre-BI cell populations differing only by the presence or absence of $P a x 5$ made it possible to investigate whether BSAP regulates the expression of other known transcription factors. As shown by the RNase protection experiment in Figure 6, the expression of the transcription factors PU.I (Scott et al. 1994), Ikaros (Georgopoulos et al. 1994), EBF (Lin and Grosschedl 1995), E2A (Bain et al. 1994; Zhuang et al. 1994), Sox-4 (Schilham et al. 1996), Oct-1 (Sturm et al. 1988), Oct-2 (Corcoran et al. 1993), and OBF-1 (Kim et al. 1996; Schubart et al. 1996) was unaffected at the mRNA level by the absence of Pax5. Similarly, the Pax 5 mutation did neither influence transcription of the recombination activating genes $R A G-1$ (Schatz et al. 1989) and RAG-2 (Oettinger et al. 1990) nor expression of the germ-line transcript $I \mu$ which initiates within the $I g H$ enhancer region (Lennon and Perry 1985). These latter observations are in agreement with our finding that Pax5-deficient pre-BI
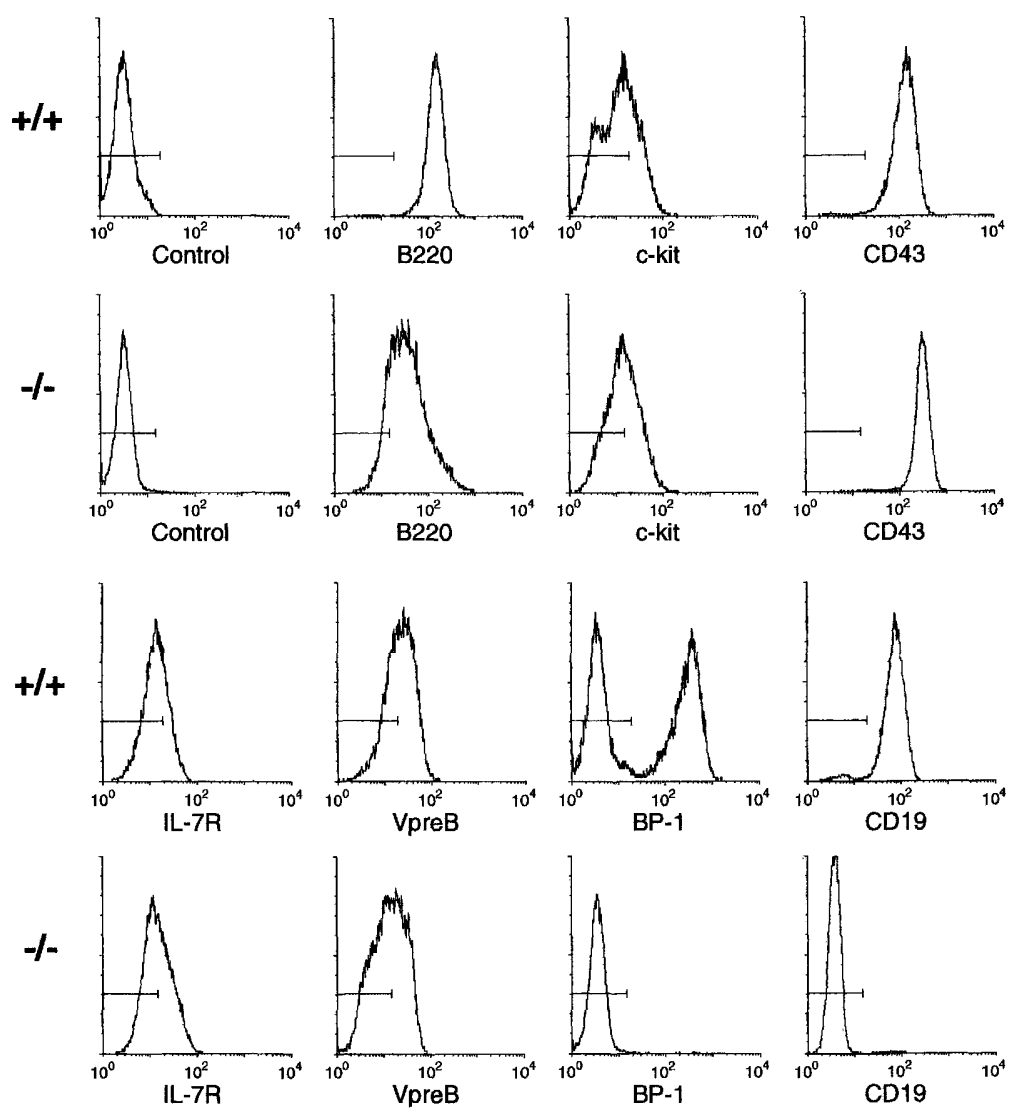

Figure 5. Cell surface phenotype of in-vitro cultured pre-BI cells from bone marrow of wild-type and Pax 5 mutant mice. Bone marrow cells from wild-type $(+/+)$ and Pax5 mutant $(-/-)$ mice at the age of 2 weeks were plated under limiting dilution conditions on ST2 cells in the presence of IL-7. For each genotype, several pre-BI cell colonies were pooled 10 days later. After 24 days in culture, the growing pre-BI cell populations were subjected to flow cytometric analysis by staining with the indicated antibodies as described in the legend to Fig. 2A. 


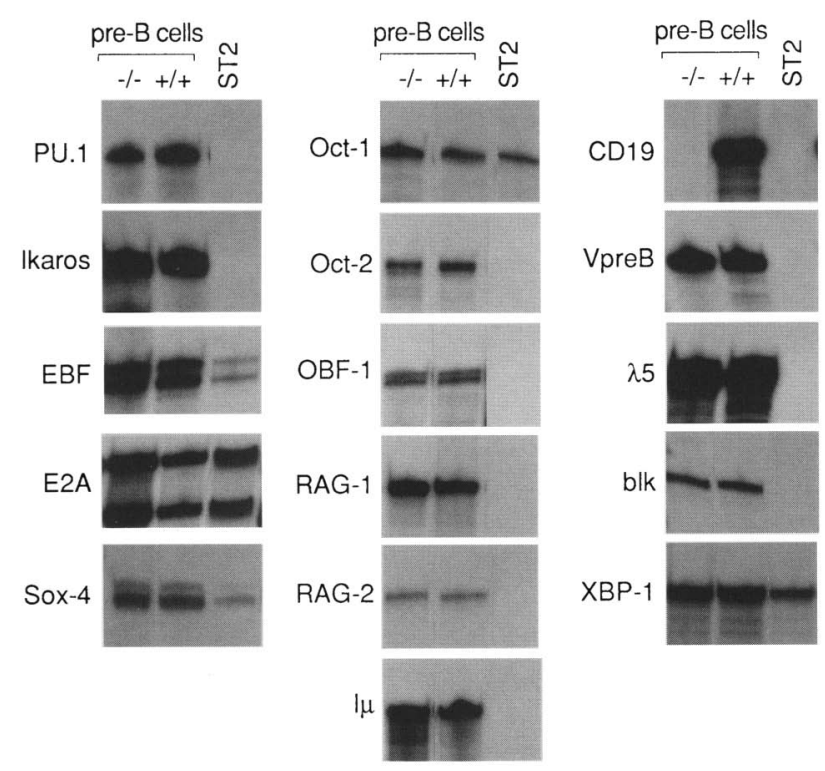

Figure 6. Gene expression in Pax5-deficient pre-BI cells. Pre-B cells isolated from bone marrow of wild-type $(+/+)$ and Pax5 mutant $(-/-)$ mice were propagated in vitro on stromal ST2 cells in the presence of IL-7. Total RNA $(10 \mu \mathrm{g})$ prepared from the two pre-B cell populations and ST2 cells was analyzed by RNase protection assay for the presence of the gene transcripts indicated at left. For the generation of different riboprobes see Materials and Methods. Only the relevant parts of the autoradiograph containing the RNase-protected fragments are shown.

cells are capable of $D_{\mathrm{H}} J_{\mathrm{H}}$ recombination at the $I g H$ locus (Fig. 3).

The B-cell-specific genes coding for CD19 (Kozmik et al. 1992), Blk (Zwollo and Desiderio 1994), XBP-1 (Reimold et al. 1996), $\lambda 5$, and VpreB1 (Okabe et al. 1992) have been suggested to be direct targets for regulation by the transcription factor BSAP (Pax5). However, of all these genes, only transcription of $C D 19$ was reduced in the absence of Pax5 (Fig. 6). Interestingly, not even basallevel expression of the $C D 19$ gene could be detected in Pax5-deficient pre-BI cells in agreement with the observation that the CD19 protein was absent from the surface of these cells (Fig. 5). These data therefore provide genetic evidence that $C D 19$ expression is critically dependent on BSAP in contrast with the other genes tested.

\section{Absence of B lymphopoiesis in the fetal liver of Pax5 mutant embryos}

During embryogenesis, B-cell development occurs predominantly in the fetal liver, which is highly enriched in B $220^{+} \mathrm{c}-\mathrm{kit}^{+} \mathrm{B}$ lymphocytes. These cells can be cloned from wild-type embryos at a high frequency in the presence of stromal cells and IL-7 (Rolink et al. 1993). Consistent with this notion, we could readily establish preB-cell lines from fetal liver of wild-type $(+\mid+)$ and heterozygous mutant $(+/-)$ embryos at day 17 (Fig. 7A). Much to our surprise however, we failed to clone any pre-B cells from the fetal liver of nine embryos lacking Pax5
$(-/-)$ (Fig. 7A). This finding suggested strongly that the fetal liver is unable to support the development of early B-lymphoid progenitors in the absence of Pax5. This conclusion was confirmed by flow cytometric analysis of liver cells from day-17 fetuses (Fig. 7B). B lymphocytes identified by the expression of the B-cell markers B220 and CD19 constitute only a small subset $(3-4 \%)$ of all cells at this developmental age both in wild-type and heterozygous mutant embryos. Most of these B lymphocytes correspond, however, to progenitor cells as defined by the expression of c-kit on their cell surface. This progenitor cell population was entirely absent in the fetal liver of Pax5 mutant embryos (Fig. 7B). To corroborate this result at the molecular level, we have analyzed, by RNase protection assay, the expression of the B-cell-specific genes B29, $\lambda 5$, VpreB1, and $E B F$ in fetal liver of wild-type and mutant embryos (Fig. 8A). All of these genes are transcribed in a Pax5-independent manner at early stages of B-cell development as shown by their expression in Pax5-deficient pre-BI cells of bone marrow (Fig. 6; unpubl. data). However, these genes were expressed in the fetal liver of homozygous mutant embryos
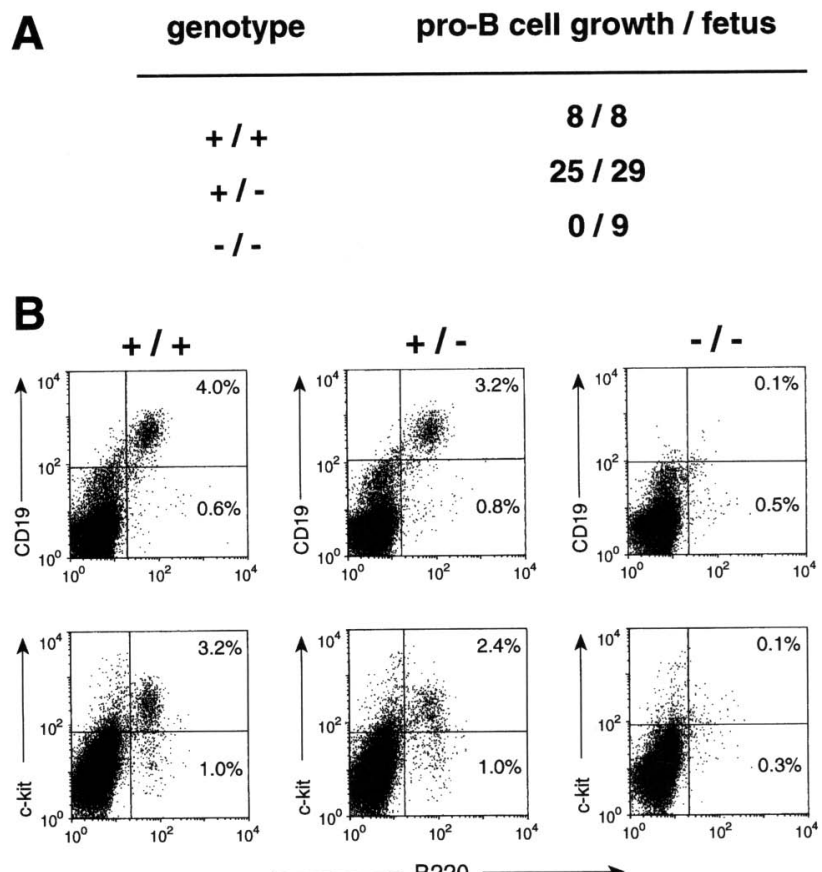

Figure 7. Absence of pro-B cells in the fetal liver of $\operatorname{Pax} 5 \mathrm{mu}$ tant embryos. $(A)$ Summary of the in vitro cloning experiments. Fetal liver cells from wild-type $(+\mid+)$, heterozygous $(+\mid-)$, and homozygous $(-/-)$ mutant embryos at day 17 were plated under limiting dilution conditions on ST2 cells in the presence of IL-7. Individual colonies were pooled, and their growth was assessed after 3 weeks of in vitro culture. $(B)$ Flow cytometric analysis. Fetal liver cells from day-17 embryos of the indicated genotypes were analyzed by flow cytometry using FITC-conjugated antiB220/CD45R (RA3-6B2) and biotinylated anti-CD19 (1D3) or anti-c-kit (ACK4) antibodies (revealed by incubation with PEcoupled streptavidin). The percentages of $\mathrm{B} 220^{+}$cells are indicated in each quadrant. 


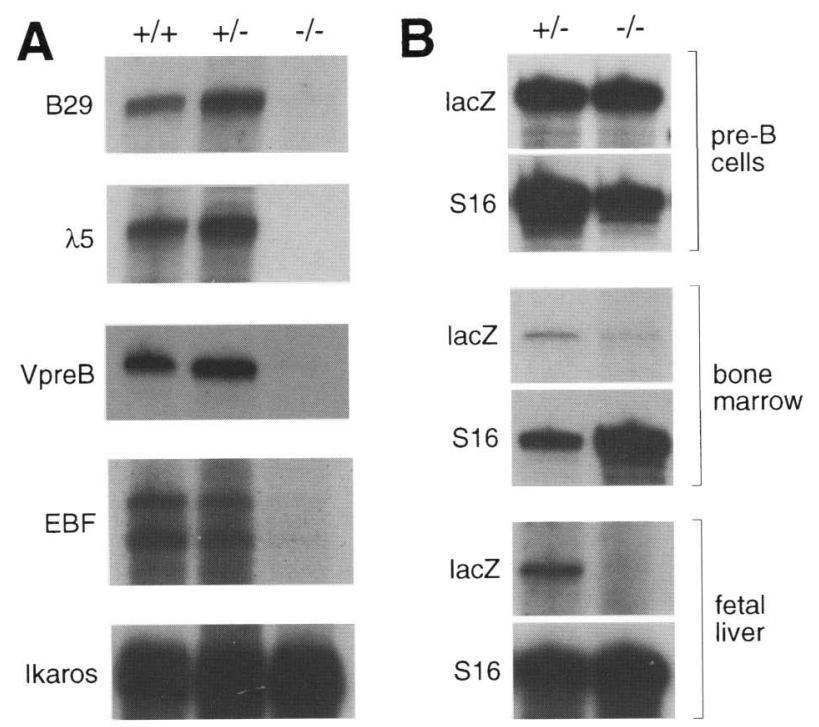

Figure 8. Dramatic reduction of B-cell-specific gene expression in fetal liver of Pax 5 mutant embryos. $\{A\}$ Expression of B-cellspecific genes in fetal liver cells. Total RNA was isolated from fetal liver of day-18.5 embryos of all three genotypes, and $20 \mu \mathrm{g}$ of each RNA preparation was analyzed by RNase protection assay with riboprobes specific for the gene transcripts indicated at left. Only the relevant parts of the autoradiographs containing the RNase-protected signals are shown. (B) lacZ expression in Pax5 mutant B lymphocytes. LacZ mRNA transcribed from the targeted Pax5 locus (Urbánek et al. 1994) was detected by RNase protection assay in total RNA isolated from in vitro cultured bone marrow pre-B cells, from bone marrow of 16/19. day-old mice and from fetal liver of day- 18.5 embryos of heterozygous $|+|-\mid$ and homozygous $|-|-\mid$ mutant genotype. Transcripts coding for the small ribosomal protein S16 were comapped as internal reference RNA.

only at a very low level, if at all, compared with wildtype and heterozygous embryos (Fig. 8A). In contrast, the Ikaros gene was equally well transcribed in the fetal liver of all three genotypes consistent with its broader expression pattern within the hematopoietic system (Georgopoulos et al. 1994). In summary, the combined results of three experimental approaches (in vitro cloning, flow cytometry, and expression analysis) demonstrate that mutation of the Pax5 gene arrests B lymphopoiesis in the fetal liver at an even earlier developmental stage than in bone marrow.

The two distinct phenotypes could in principle result from a difference in the developmental onset of Pax5 expression during fetal and adult $\mathrm{B}$ lymphopoiesis. To address this question, we have taken advantage of the fact that the targeted Pax 5 allele carries an Escherichia coli lacZ gene under the transcriptional control of the endogenous locus (Urbánek et al. 1994). RNase protection analysis of lac $Z$ mRNA was therefore used to monitor Pax 5 expression in bone marrow, fetal liver, and in vitro cultured pre-BI cells of heterozygous and homozygous mutant mice. As shown in Figure 8B, the lacZ gene was transcribed in both pre-B- cell lines to a similar level. In agreement with this observation, lac $Z$ transcripts were also detected in bone marrow, where the disparity in transcript levels reflects the difference in B-lymphocyte numbers between heterozygous and homozygous mutant mice (Urbánek et al. 1994). We conclude therefore that the Pax 5 gene is transcribed even before the developmental stage at which B-cell differentiation is aborted in the bone marrow of Pax5-deficient mice. In contrast, no Pax5 transcripts could be detected in the fetal liver of homozygous mutant embryos (Fig. 8B), therefore indicating that $\operatorname{Pax} 5$ is essential for fetal Blymphopoiesis right from the onset of its expression.

\section{B-cell-autonomous effect of the Pax5 mutation}

Early lymphocyte development is dependent strictly on the interaction with appropriate stromal cells in the primary lymphoid organs (Rolink and Melchers 1991). Interestingly, stromal cells of the thymus express Pax-1, another member of the Pax family, and mutation of this gene in undulated mice interferes with stromal cell differentiation, therefore resulting in abnormal T-cell development (Wallin et al. 1996). In analogy to this situation, it is also conceivable that a primary site of Pax 5 function could be the stromal cells in bone marrow and that the block of B-cell development is merely the secondary consequence of abnormal stromal cell differentiation in Pax5 mutant mice. To distinguish between such an indirect mode of action and a cell-autonomous effect of the Pax5 mutation, we have reconstituted lethally irradiated wild-type mice by transplantation of bone marrow cells from Pax5-deficient donor mice. Three months after cell transfer, the reconstituted bone marrow of these mice contained only $\mathrm{B} 220^{+} \mathrm{CD} 43^{+} \mathrm{B}$ lymphocytes, as shown by flow cytometric analysis (Fig. 9A). The majority of these cells also expressed c-kit and IL-7R on their surface, which further identifies them as pre-BI cells. The absence of CD19 expression on these B lymphocytes demonstrated efficient reconstitution of the bone marrow by Pax5 mutant donor cells. As illustrated by the absence of the late differentiation marker IgM and CD40, B-cell development was, however, still blocked completely in all B-lymphoid progenies of the transferred Pax5-deficient stem cell that was now embedded in wild-type tissue. We conclude, therefore, that the effect of the Pax5 mutation is B-cell autonomous.

To further investigate the nature of the early block in fetal B lymphopoiesis, we have also used fetal liver cells of Pax 5 mutant embryos to reconstitute the hematopoietic system of lethally irradiated wild-type mice (Fig. 9B). Interestingly, the bone marrow of these reconstituted mice was able to generate pre-BI cells expressing CD43, c-kit, and IL-7R quite in contrast with the fetal liver of the donor embryos. The B-cell phenotype is therefore identical in reconstituted mice regardless of whether Pax5-deficient fetal liver or bone marrow cells were used for transplantation. These data indicate that different functions of $\operatorname{Pax} 5$ are required to support early B-cell 

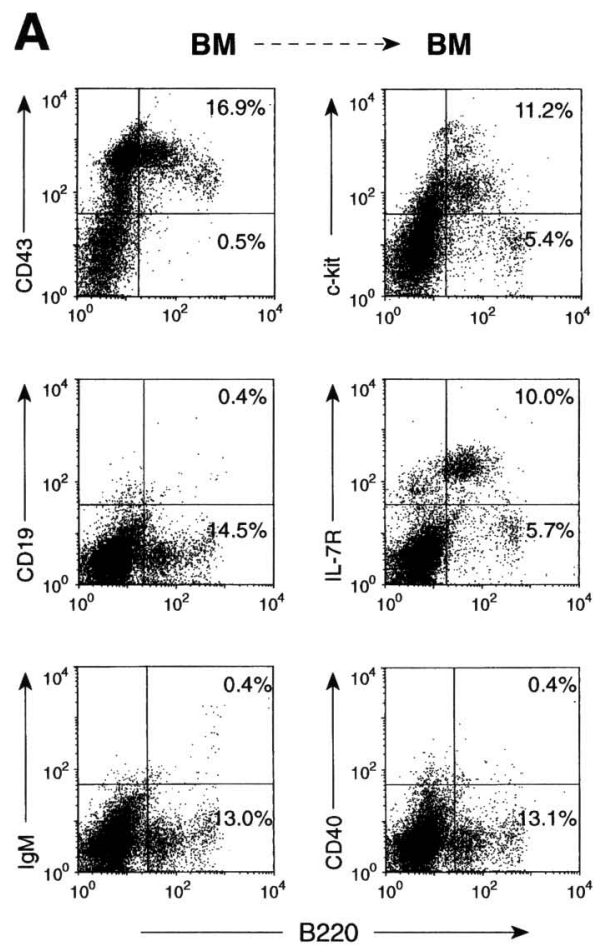
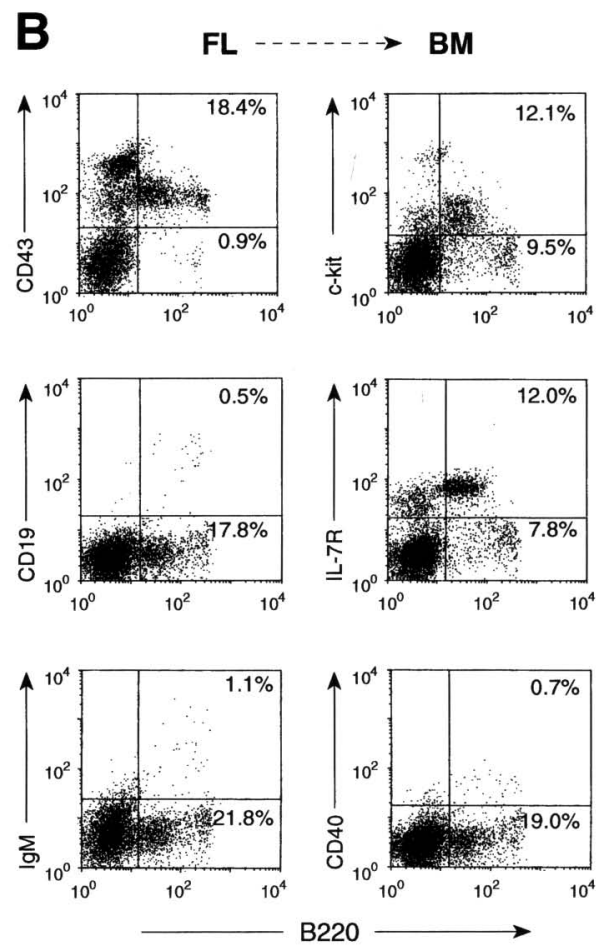

Figure 9. Cell autonomous effect of the Pax5 mutation in B-cell development. $(A)$ Reconstitution of the hematopoietic system with bone marrow of Pax5-deficient mice. The hematopoietic system of lethally irradiated wild-type mice was reconstituted by transplantation of bone marrow (BM) cells from 16-day-old homozygous Pax5 mutant mice (see Materials and Methods). (B) Reconstitution with Pax5-deficient fetal liver cells. Lethally irradiated wild-type mice were rescued by injection of fetal liver (FL) cells from day-13.5 embryos lacking Pax5. In both cases, the B-cell compartment in the bone marrow of reconstituted mice was analyzed 3 months after transplantation by flow cytometry as described in the legend to Fig. 2A and in Materials and Methods.

development in the distinctive microenvironments of fetal liver and adult bone marrow.

\section{Discussion}

Differential dependency of fetal and adult pro-B-cell development on Pax5

The developmental control genes of the Pax family are associated with mouse mutants and human disease syndromes and code for transcription factors with important functions in embryonic pattern formation (for review, see Stuart et al. 1994). One member of this gene family, Pax5, has an essential role not only in the morphogenesis of the developing midbrain, but also in early B lymphopoiesis (Urbánek et al. 1994). Here we have demonstrated that B-cell development is arrested at the early pro-B (pre-BI) cell stage in the bone marrow of Pax5-deficient mice. The B lymphocytes of these mice were identified as pre-BI cells on the basis of their expression of c-kit, IL-7R, CD43, HSA, $\lambda 5$, and VpreB as well as by the absence of CD25, BP-1, and later differentiation markers on the cell surface (see Fig. 1). Moreover, these Pax5-deficient pre-BI cells could be cultured in vitro in the presence of stromal cells and IL-7 with the same efficiency as the corresponding cells from wild-type bone marrow. Pre-BI cells could, however, not be detected in the fetal liver of Pax 5 mutant embryos as shown by the lack of in vitro clonable $B$ lymphocytes and by an almost complete absence of B-cell-specific gene expression. $\operatorname{Pax} 5$ is therefore required at two different developmental stages in fetal and adult B lymphopoiesis (Fig. 10). In adult bone marrow, Pax 5 is essential for progression of B-cell development beyond the early pre-BI cell stage, whereas in the fetal liver it is required already for differentiation of the earliest B-lineage-committed precursor cells. Bone marrow transplantation experiments furthermore demonstrated that the developmental block in adult B-lymphopoiesis results from a direct, cell autonomous effect of the Pax 5 mutation on B-cell differentiation instead of being the indirect consequence of an interference with stromal cell differentiation. Interestingly, Pax5-deficient fetal liver cells could give rise to the development of pre-BI cells in reconstituted bone marrow, contrary to the situation encountered in the embryo. This apparent discrepancy may indicate a critical function of Pax 5 for stromal cell development in the fetal liver, although there is to date no evidence for Pax5 expression in these cells. Therefore, we consider it more likely that the earliest B-cell progenitors depend for development or survival in the fetal liver microenvironment on their own expression of BSAP (Pax5) target genes that are not essential for pro-B cell development in 


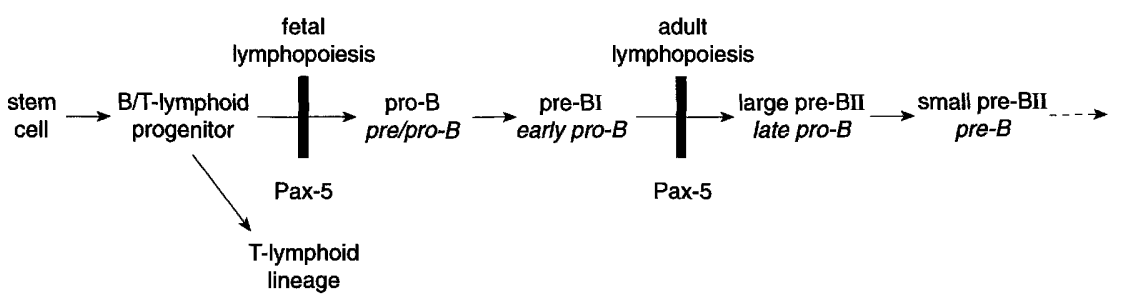

Figure 10. Differential dependency of pro-B cell development on Pax5 in fetal and adult B lymphopoiesis. A schematic diagram of early B-cell differentiation is shown together with the developmental block observed in fetal and adult B lymphopoiesis of Pax 5 mutant mice. The different developmental stages are referred to in the nomenclature of Rolink et al. (1994) (top line) and Hardy et al. (1991) (bottom line in italics). adult bone marrow. Consistent with this notion, Pax5 expression is indispensable right from its onset in fetal B lymphopoiesis, whereas its expression in pre-BI cells of the bone marrow does not appear to fulfill a critical function during early pro-B cell development.

Differences between fetal and adult B lymphopoiesis have been observed previously. The enzyme terminal deoxynucleotidyl transferase (TdT), which is responsible for $\mathrm{N}$ sequence insertions in the $D_{\mathrm{H}} /_{\mathrm{H}}$ and $V_{\mathrm{H}} D_{\mathrm{H}} /_{\mathrm{H}}$ joints of the $I g H$ gene, is not expressed in lymphocytes of the fetal liver in contrast to bone marrow (Desiderio et al. 1984; Li et al. 1993). Similarly, the B-lymphoid-specific myosin light chain gene PLRLC is transcribed only in pre-B cells of the bone marrow, but not in fetal liver cells (Oltz et al. 1992; Li et al. 1993). The hematopoietic progenitor cells of fetal liver and bone marrow also differ in their capacity to regenerate the two different B-cell subsets consisting of the conventional $\mathrm{CD}^{-} \mathrm{B}$ lymphocytes and the CD5-expressing B-1 cells (for review, see Hardy and Hayakawa 1994; Kantor and Herzenberg 1993). Fetal liver cells can efficiently reconstitute both B-cell populations in transplantation experiments, whereas bone marrow cells of adult donor mice predominantly give rise to conventional B lymphocytes (Kantor et al. 1992; Hardy and Hayakawa 1994). These phenotypic differences are most probably not related to any Pax 5 function as both B-cell populations are equally dependent on this transcription factor for their development (Urbánek et al. 1994). To our knowledge, however, Pax 5 provides the first example of a transcription factor with distinct roles in fetal and adult B lymphopoiesis.

The Pax 5 gene is expressed in the B-lymphoid lineage up to the mature B-cell stage and consequently has also been implicated in the regulation of different aspects of late B-cell differentiation (for review, see Busslinger and Urbánek 1995). For instance, Pax5 is considered to be involved in the proliferation control of mature B lymphocytes, as antisense oligonucleotide inhibition of BSAP synthesis prevented splenic B-cells from entering the cell cycle on mitogenic stimulation (Wakatsuki et al. 1994). This hypothesis has recently gained support by the discovery that Pax5 is recruited as an oncogene by $\mathrm{t}(9: 14)(\mathrm{p} 13 ; \mathrm{q} 32)$ translocations in a subset of nonHodgkin's lymphomas (Busslinger et al. 1996). This type of chromosomal translocation inserts the E $\mu$ enhancer of the $I g H$ locus upstream of two Pax5 promoters, which may interfere with the down-regulation of Pax5 expression during plasma cell differentiation (Busslinger et al. 1996). In this regard it is, however, important to note that the early pre-BI cells of both wild-type and Pax5deficient mice proliferate equally well in vivo and in vitro. Therefore, the proliferation of B lymphocytes does not require Pax 5 expression early in the lineage, but may become dependent on this transcription factor at later stages of B-cell differentiation.

Targeted gene inactivation in the mouse germ line was also used to elucidate the function of other transcription factors in the genetic control of B-cell differentiation. PU.1, a member of the Ets transcription factor family, appears to act high up in the transcriptional hierarchy, as disruption of its gene prevents the generation of progenitors for both the lymphoid and myeloid lineages (Scott et al. 1994). Deletion of a subset of the zinc finger proteins encoded by the Ikaros locus results in complete failure of B- and T-cell development (Georgopoulos et al. 1994). Once committed to the B-lymphoid lineage, cells become dependent on the function of the $E B F$ and $E 2 A$ genes in addition to Pax5. Mice lacking the early B-cell factor EBF (Lin and Grosschedl 1995) or the helix-loophelix transcription factors E12 and E47 encoded by the E2A gene (Bain et al. 1994; Zhuang et al. 1994) are able to generate only a small number of $\mathrm{CD} 43^{+} \mathrm{B} 22 \mathrm{O}^{+}$cells in the bone marrow. In both cases, these early pro- $B$ cells express a very limited set of B-cell-specific genes, contain the $I g H$ locus still in germ-line configuration and do not transcribe the Pax5 gene (Bain et al. 1994; Lin and Grosschedl 1995). B-cell development appears therefore to be blocked at an earlier stage in the bone marrow of $E B F$ and E2A mutant mice compared with animals lacking Pax5. However, a different situation prevails in fetal liver where Pax 5 is already required for full commitment to the B-lymphoid lineage. Progression of B-cell development to the small pre-B-cell stage is furthermore dependent on the function of the transcription factor Sox-4 (Schilham et al. 1996), whereas Oct-2, OBF-1, and the p50 subunit of NF- $\mathrm{\kappa B}$ have critical roles in the activation of mature B-cells to undergo plasma cell differentiation (Corcoran et al. 1993; Sha et al. 1995; Kim et al. 1996; Schubart et al. 1996). Importantly, the expression of none of these regulatory genes was affected in Pax5-deficient pre-BI cells. Therefore, Pax5 does not appear to exert its effect on B-cell development by controlling the expression of other known transcription factors.

Pax5 and the B-cell-specific control of $\mathrm{V}(\mathrm{D}) \mathrm{J}$ recombination

The somatic assembly of immunoglobulin heavy- and 
light-chain genes from different coding segments is achieved in a highly regulated and temporally ordered fashion by the site-specific $V(D) T$ recombination system (for review, see Lewis 1994). Joining of the $D_{\mathrm{H}}$ and $J_{\mathrm{H}}$ segments is initiated at the $\operatorname{IgH}$ locus soon after B-cell lineage commitment, and this process is completed on both $\mathrm{IgH}$ alleles at the early pro-B (pre-BI) cell stage (Ehlich et al. 1993; Li et al. 1993). At this time in B-cell development, $V_{\mathrm{H}}$-to- $D_{\mathrm{H}} J_{\mathrm{H}}$ recombination is activated and then continues to operate until the late pro-B-cell stage (large pre-BII) (Ehlich et al. 1993; Li et al. 1993) when surface expression of a functionally rearranged $\mu$ heavy-chain protein signals allelic exclusion and therefore prevents further rearrangement at the $\operatorname{IgH}$ locus (Kitamura and Rajewsky 1992). Using different PCR assays, we have demonstrated that the majority of the preBI cells in Pax5-deficient mice contain the IgH locus in the $D_{\mathrm{H}} / \mathrm{H}^{-}$-rearranged configuration. The frequency of $V_{\mathrm{H}^{-}}$ $D_{\mathrm{H}} /_{\mathrm{H}}$ rearrangements is, however, reduced 50 -fold in Pax5-deficient pre-BI cells compared with wild-type cells. These results therefore suggest an involvement of Pax 5 in the pathway controlling $V_{\mathrm{H}^{-}}$to- $D_{\mathrm{H}} J_{\mathrm{H}}$ recombination.

The chromatin accessibility of the recombination substrates appears to be a key factor in the control of the $V(D) J$ rearrangement process as indicated by the observation that the transcription of germ-line immunoglobulin gene segments usually precedes their DNA rearrangement (Yancopoulos and Alt 1985; Schlissel and Baltimore 1989; Schlissel et al. 1991b). Transcriptional activation may therefore target immunoglobulin genes for $V(D) J$ recombination. In agreement with this hypothesis, $V(D) J$ recombination is impaired by germ-line deletion of the intronic enhancers of the $\mathrm{IgH}$ locus (Chen et al. 1993; Serwe and Sablitzky 1993) and IgLk gene (Takeda et al. 1993) or by the lack of the $E \mu$ enhancer on transgenic recombination substrates (Ferrier et al. 1990). As both intronic enhancers do not contain any high-affinity binding sites for BSAP (Barberis et al. 1990), it is unlikely that Pax 5 mediates its effect on $V(D) /$ recombination by direct interaction with these regulatory regions. Alternatively, Pax 5 may control $V_{\mathrm{H}^{-}}$-to- $D_{\mathrm{H}} J_{\mathrm{H}}$ rearrangements by activating germ-line $V_{\mathbf{H}}$ gene transcription. The promoter activity of $V_{\mathrm{H}}$ and $V_{\mathrm{K}}$ genes is known to critically depend on a regulatory sequence that is bound by the transcription factors Oct-1 and Oct-2 (Falkner and Zachau 1984; Mason et al. 1985). However, both of these transcriptional regulators as well as their B-cell-specific coactivator OBF-1 (Kim et al. 1996; Schubart et al. 1996) are equally well expressed in the presence or absence of Pax5. To date we therefore do not have any evidence for either a direct or indirect role of $\operatorname{Pax} 5$ in transcriptional regulation underlying the $V_{\mathrm{H}} D_{\mathrm{H}} J_{\mathrm{H}}$ rearrangement process.

It has been known for some time that $D_{\mathrm{H}} /_{\mathrm{H}}$ rearrangements at the $I g H$ locus promiscuously occur also in cells of the T-lymphoid lineage (Born et al. 1988; Cory et al. 1980; Kurosawa et al. 1981). In contrast, $V_{\mathbf{H}^{-}}$to- $D_{\mathrm{H}} J_{\mathbf{H}}$ rearrangements of the $I g H$ gene take place only in B lymphocytes and therefore constitute a more stringently regulated step of the $V(D) I$ recombination process. The ubiquitously expressed transcription factors of the E2A gene have been implicated in the control of $D_{\mathrm{H}} /_{\mathrm{H}}$ rearrangements both by gain- and loss-of-function experiments. Ectopic expression of the $\mathrm{E} 47$ protein resulted in the activation of $D_{\mathrm{H}} J_{\mathrm{H}}$, but not of $V_{\mathrm{H}} D_{\mathrm{H}} J_{\mathrm{H}}$ rearrangements in a pre-T-cell line (Schlissel et al. 1991a). Moreover, the pro-B-cells of E2A-deficient mice neither express the recombination activating gene RAG-1 nor do they undergo $D_{\mathrm{H}}$-to- $J_{\mathrm{H}}$ rearrangements at the $I g H$ locus (Bain et al. 1994). Here we have shown that loss of the B-cell-specific transcription factor BSAP (Pax5) affects the B-lymphoid-restricted $V_{\mathrm{H}^{-}}$to- $D_{\mathrm{H}} J_{\mathrm{H}}$ joining step of $I g H$ assembly. In this context it is of interest to note that the B-cell phenotype of Pax5-deficient mice differs at least in two aspects from that of mice with targeted disruption of genes involved in the expression of the pre-Bcell receptor. First, based on the expression of cell surface markers, B-cell development appears to be arrested at an earlier stage in $\mathrm{Pax} 5$ mutant mice (early pro-B cells; fraction $\mathrm{B})$ than in mice lacking $R A G-1, \operatorname{Ig} \beta, \lambda 5(\lambda 5 \mathrm{~T})$, the joining region $\left(J_{\mathrm{H}} \mathrm{T}\right)$ or the membrane exon $(\mu \mathrm{MT})$ of the $\mathrm{IgH}$ locus, all of which are blocked at the late pro-B-cell stage (fraction C) (Ehlich et al. 1993; Spanopoulou et al. 1994; Gong and Nussenzweig 1996). Second, expression of a rearranged $\mu$ heavy-chain transgene in Pax 5 mutant mice did not allow B lymphocytes to advance in B-cell development (C. Thévenin and $M$. Busslinger, unpubl.) in contrast with the situation observed with RAG-deficient mice where complementation with a $\mu$ transgene facilitates progression to the small pre-B cell stage (Rolink et al. 1994; Spanopoulou et al. 1994; Young et al. 1994). The lack of complementation therefore indicates that the failure to undergo $V_{\mathrm{H}^{-}}$-to- $D_{\mathrm{H}} /_{\mathrm{H}}$ rearrangements is unlikely to be the reason for the developmental block observed in the bone marrow of Pax 5 mutant mice.

\section{Regulation of B-cell-specific gene expression by BSAP (Pax5)}

Insight into the regulatory function of BSAP critically depends on the identification of genes that are controlled by this transcription factor. The in vitro clonability of Pax5-deficient pre-BI cells now provides a useful tool to search for such target genes. Comparative expression analysis of over 30 known B-cell-specific genes in wildtype and Pax5-deficient pre-BI cells resulted in the identification of three genes, $C D 19, m b-1(\operatorname{Ig} \alpha)$ and N-myc, which are down-regulated in the absence of BSAP at this early stage of B-cell development. Whereas the levels of $\mathrm{N}-m y c$ and $m b-1$ transcripts were reduced consistently (S. Nutt, unpubl.), expression of the CD19 gene was entirely lost in Pax5-deficient pre-BI cells (Fig. 6). In accord with this finding, we have identified previously a highaffinity BSAP-binding site in the -30 region of the CD19 gene, which is fully occupied in vivo in B cells and is therefore likely to mediate BSAP-dependent transcriptional initiation (Kozmik et al. 1992). Moreover, CD19 expression can be induced readily in an estrogen-dependent manner in Pax5-deficient pre-BI cells expressing a 
BSAP-estrogen receptor fusion protein (S. Nutt, unpubl.). Together, these data unequivocally identify CD19 as a genuine BSAP target gene. The expression of $b 1 k, X B P-1$, $\lambda 5$, and VpreB1 was, however, unaffected by the absence of BSAP, which strongly argues against a critical role of this transcription factor in the regulation of these genes in apparent contradiction to published data (Okabe et al. 1992; Zwollo and Desiderio 1994; Reimold et al. 1996).

Could the lack of CD19 expression be responsible for the early arrest of B-cell development in Pax5-deficient mice? The CD19 protein is known to associate with surface immunoglobulin receptors where it acts as a costimulatory molecule to lower the threshold for antigendependent signaling (Carter and Fearon 1992). In agreement with this function, the processes of B-cell activation, selection and maturation are impaired severely in mice lacking CD19 (Engel et al. 1995; Rickert et al. 1995). However, B-lymphoid development up to the mature B-cell stage was unperturbed in the bone marrow of these mice, demonstrating that CD19 cannot be one of the critical target genes responsible for the differentiation block in Pax 5 mutant mice. Therefore, we will have to face the challenge to systematically search for such target genes, which should be facilitated greatly by the availability of Pax5-deficient pre-BI cell lines.

\section{Materials and methods}

Mice

All analyses including the bone marrow transplantation experiments were performed with wild-type and Pax 5 mutant mice that were bred on the hybrid background C57BL/6 $\times 129 / \mathrm{Sv}$ (Urbánek et al. 1994). The Pax5 genotype was determined by Southern blot analysis (Urbánek et al. 1994) or by PCR assay using the following oligonucleotides: 5'-ACAGTCCCCTTACCCCTTCCCCCAAATGAA-3' (primer 1); 5'-GTCCCTCCTAACAAAGTCTCCCTATTCCAC-3' (primer 2); and 5'-GTGAGCGAGTAACAACCCGTCGGATTCTCC-3' (primer 3). A 693-bp PCR product was amplified from the wild-type Pax 5 allele with primer pair $1 / 2$ and a 783 -bp DNA fragment from the mutant $l a c Z$ allele with the pair $1 / 3$.

\section{Antibodies and flow cytometric analysis}

The following monoclonal antibodies were purified from hybridoma cell supernatants on protein G-sepharose columns (Pharmacia, Uppsala, Sweden) and conjugated with Sulfo-NHSBiotin (Pierce Chemical Company) as recommended by the suppliers: anti-CD19 mAb (1D3; Krop et al. 1996), anti-c-kit mAb (ACK4; Ogawa et al. 1991), anti-IL-7R mAb (A7R34; Sudo et al. 1993), anti-VpreB mAb (VP245; Karasuyama et al. 1993), and anti- $\mu \mathrm{H}$ chain mAb (M41; Leptin et al. 1984). Anti-B220/ $\mathrm{CD} 45 \mathrm{R} \mathrm{mAb}$ (RA3-6B2) was obtained as fluorescein isothiocyanate (FITC)-conjugated antibody from PharMingen (San Diego, CA), whereas all other monoclonal antibodies were purchased from the same company in biotinylated form: anti-CD25/TAC $\mathrm{mAb}$ (7D4), anti-CD43 (S7), anti-BP-1 (6C3), and anti-HSA/ CD24 (Ml/69). Phycoerythrin (PE)-conjugated streptavidin was obtained from Southern Biotechnology Associates Inc. (Birmingham, Alabama).

Single-cell suspensions were prepared from bone marrow and fetal liver, stained with different antibody combinations and then analyzed by a FACScan flow cytometer (Becton-Dickinson) as described previously (Urbánek et al. 1994).

\section{Fluorescence-activated cell sorting and cell cycle analysis}

Bone marrow cells of 2-week-old Pax5 mutant mice were stained with anti-B220/CD45R (RA3-6B2) and anti-c-kit (ACK4) antibodies and then separated into $\mathrm{B} 220^{+} \mathrm{c}-\mathrm{kit}^{+}$and $\mathrm{B} 220^{+} \mathrm{c}-\mathrm{kit}^{-}$cell fractions by fluorescence-activated cell sorting using a FACStar plus flow cytometer. Reanalysis of the sorted cells indicated a purity of $\geqslant 90 \%$ for each cell population. Cell cycle analysis was performed by fixing the sorted cells followed by ethidium bromide staining of isolated nuclei and FACScan analysis of their DNA content as described previously /Rolink et al. 1994).

\section{Transplantation of bone marrow and fetal liver cells}

Wild-type female mice (C57BL/6 $\times 129 / \mathrm{Sv}$ ) at the age of 2 months were lethally $\gamma$-irradiated with $950 \mathrm{rads}(9.5 \mathrm{~Gy})$ and then provided with $2 \times 10^{6}$ to $7 \times 10^{6}$ bone marrow cells from 16-day-old homozygous Pax 5 mutant mice (C57BL/ $6 \times 129 / \mathrm{Sv}$ ) by injection into the tail vein. In a second experimental series, wild-type recipient mice of the same age and strain background were lethally irradiated and subsequently received $3 \times 10^{6}$ to $5 \times 10^{6}$ fetal liver cells prepared from day-13.5 embryos (C57BL/ $6 \times 129 / \mathrm{Sv}$ ) lacking Pax5. The B-cell compartment of the recipient mice was analyzed by flow cytometry 3 months after cell transfer.

\section{$P C R$ analysis of $\operatorname{IgH}$ gene rearrangements}

Single-cell PCR analyses (Fig. 3) were performed with individual $\mathrm{B} 220^{+} \mathrm{c}-\mathrm{kit}^{+}$cells that were sorted from bone marrow of twoweek-old Pax 5 mutant mice into single wells of a 96-well plate by a FACStar ${ }^{\text {plus }}$ flow cytometer. The $I g H$ and $I g L_{\kappa}$ gene loci of individual cells were amplified exactly according to the twostep PCR protocol of ten Boekel et al. (1995), which is based on the method of Ehlich et al. (1994). Only the first (Gu et al. 1991) of the two $D_{\mathrm{H}} \mathrm{FL} 16 / D_{\mathrm{H}} \mathrm{SP} 2$-specific $5^{\prime}$ primers listed in Table 1 of ten Boekel et al. (1995) was used for PCR amplification of $D_{\mathrm{H}} / \mathrm{H}_{\mathrm{H}}$-rearranged alleles which resulted in DNA fragments of the following sizes: $1880 \mathrm{bp}\left(J_{\mathrm{H}} 1\right), 1560 \mathrm{bp}\left(J_{\mathrm{H}} 2\right), 1180 \mathrm{bp}\left(J_{\mathrm{H}} 3\right)$, and $610 \mathrm{bp}\left(J_{\mathrm{H}} 4\right)$. The products of the second PCR reaction were cloned directly into the dT-tailed vector pCRII (Invitrogen) and then verified by DNA sequencing.

The same two-step PCR protocol was also employed for the amplification of rearranged $I g H$ alleles from $10,000 \mathrm{~B} 220^{+} \mathrm{c}-\mathrm{kit}^{+}$ cells that were sorted from the bone marrow of either wild-type or Pax5-deficient mice. Only 25 cycles of amplification were used for each of the two PCR reactions, and the amplified DNA fragments were analyzed by Southern blot hybridization with a $120-\mathrm{bp} J_{\mathrm{H}} 4$-specific DNA probe. In this assay, $V_{\mathrm{H}} D_{\mathrm{H}} J_{\mathrm{H}}$ recombination generated DNA fragments of the following sizes: 1720 bp $\left(J_{\mathrm{H}} 1\right), 1410 \mathrm{bp}\left(J_{\mathrm{H}} 2\right), 990 \mathrm{bp}\left(J_{\mathrm{H}} 3\right)$ and $460 \mathrm{bp}\left(J_{\mathrm{H}} 4\right)$. A 1500-bp PCR product was indicative of the $I g H$ germ-line configuration.

For quantitation of $V_{\mathrm{H}} D_{\mathrm{H}} /_{\mathrm{H}}$ recombination, the rearranged alleles of the $V_{\mathrm{H}} J 558$ gene family were amplified by 30 PCR cycles with a $V_{\mathrm{H}} / 558$-specific primer pair (Ehlich et al. 1994) from increasing numbers of $\mathrm{B} 22 \mathrm{O}^{+} \mathrm{CD} 43^{+}$cells that were sorted from the bone marrow of mutant and wild-type mice. As control for the number of $\mathrm{B} 220^{+} \mathrm{CD} 43^{+}$cells analyzed, a 2050-bp fragment was amplified from the $\mathrm{C} \mu$ region of the $\mathrm{IgH}$ locus with primers described previously (Rolink et al. 1993). 


\section{Establishment of pre-B-cell lines}

Cell suspensions from bone marrow and fetal liver of wild-type and Pax5 mutant mice were plated at limiting dilutions on a semi-confluent layer of stromal cells in the presence of IL-7 medium exactly as described (Rolink et al. 1991b, 1993). ST2 cells (Ogawa et al. 1988) that were $\gamma$-irradiated with $\sim 1100$ rads $(11 \mathrm{~Gy})$ in a Gammacell 40 machine were used as stromal cells. The IL-7-containing medium consisted of Iscove's modified Dulbecco's medium (IMDM) supplemented with $2 \%$ heat-inactivated fetal calf serum, $0.03 \%$ (wt/vol) primatone RL (Quest International, Naarden, The Netherlands), $50 \mu_{M}$ 2-mercaptoethanol, $1 \mathrm{~mm}$ glutamine, and $1 \%$ conditioned supernatant of rIL-7-producing /558L cells (Rolink et al. 1993). After 1 week of in vitro culture, several pre-B-cell colonies were pooled and further propagated as a cell line.

\section{Riboprobes and RNase protection assay}

The following oligonucleotide pairs were used for PCR amplification of the indicated riboprobes: mPU.1, 5' GCGGAATTCGCGACATGAAGGACAGCATCT-3' and $5^{\prime}$ GCGAAGCTTGCTGAACTGGTAGGTGAGCTT-3'; mIkaros, 5'-GCGGAATTCGCTGCCAAGACTCCACAGATA-3' and $5^{\prime}$-GCGAAGCTTTGCTCGCCACTCGTGCTGAC-3'; mEBF, 5'-GCGGAATTCACAATAACTCCAAGCACGGG-3' and $5^{\prime}$-GCGAAGCTTGGCATGAGGAGTTATCAACTC-3'; mE2A, 5'-GCGGAATTCCCCAACTACGATGCAGGTCT-3' and $5^{\prime}$-GCGAAGCTTGAGGTCTCTGTGAGAGGTCA-3'; mSox-4, 5'-GCGAAGCTTTTATGGTGTGGTCGCAGATCG$3^{\prime}$ and 5'-GCGAAGCTTGTTGCCCGACTTCACCTTCTT-3'; mOct-1, 5'-GCGGAATTCTCCAGTGAAGAGTCGGGAGA$3^{\prime}$ and $5^{\prime}$-GCGAAGCTTATCTGTATGGGCTGAGACAGG$3^{\prime}$; mOct-2, 5'-GCGGAATTCCTGCACATGGAGAAGGAAGTG-3' and 5'-GCGAAGCTTCAGACTGCTAGAAGCTTGGGA-3'; mOBF-1，5'-GCGGAATTCACCTCCACCCTGCAGTACCA-3' and 5'-GCGAAGCTTGCCTTCCACAGAGAGAGTGTGG-3'; and $\overline{\mathrm{mVpre}^{\prime}}$ 1, 5'-GCGGAATTCTCCCAGGTTCCTGCTGAGATA-3' and $5^{\prime}$ GCGAAGCTTCGACTTTTCTCCTTCCCACTC-3'; $\operatorname{m\lambda } 5$ : $5^{\prime}$ GCGGAATTCTCAGCAGAAAGGAGCAGAGCT-3' and 5'GCGAAGCTTACACACTACGTGTGGCCTTGT-3'; mRAG1, 5'-GCGGAATTCGGAACTCCTCTCCACCAGTT-3' and 5' -GCGAAGCTTCAGCCAGTGATGTTTCAGGAC-3'; mRAG-2, 5'-GCGGAATTCGGACTCCACTCCCTTTGAAGA-3' and 5'-GCGAAGCTTATCCATCGACTGGGCATGTAC-3'; mI $\mu, 5^{\prime}$-GCGGAATTCCCTGGGAATGTATGGTTGTGG-3' and 5'-GCGAAGCTTATGGGCACATGCAGATCTCTG-3'; mB29, 5'-GCGGAATTCCTGTGGCACGGAACTTCTAGT $-3^{\prime}$ and $5^{\prime}$-GCGAAGCTTCCTGTCCGAAGAGTCACTATG- $3^{\prime}$; mXBP-1, 5'-GCGGAATTCACCATGGTGCCTAGTGTTCC-3' and 5'-GCGAAGCTTTCTGAGGAGTTGTGTGAGCT- $3^{\prime}$

cDNA transcribed from poly $(\mathrm{A})^{+} \mathrm{RNA}$ of the murine pre-Bcell line $70 \mathrm{Z} / 3$ was used as template for PCR amplification of PU.1, EBF, Oct-1, OBF-1, XBP-1, and $I \mu$ sequences with the primers indicated above. E2A, Oct-2, VpreB1, $\lambda 5, R A G-1, R A G-$ 2 , and $B 29$ sequences were amplified from the respective cDNA clone (Kudo and Melchers 1987; Kudo et al. 1987; Hermanson et al. 1988; Schatz et al. 1989; Oettinger et al. 1990; Walker et al. 1990; Wirth et al. 1991). All amplified cDNA fragments were cloned in the antisense orientation into the HindIII and EcoRI sites of pSP64. The $S 16$ and $l a c Z$ riboprobes have been described previously (Urbánek et al. 1994). A 260-bp BamHI-EcoRI fragment of plasmid pZipNeo-mCD19 (Krop et al. 1996) and a 150bp ApaI-HindIII fragment of the blk cDNA clone 102 (Dymecki et al. 1990) were inserted into the polylinker of pSP64 to obtain the $C D 19$ and blk riboprobes, respectively. All subclones were verified by DNA sequencing.

Total RNA was prepared from mouse tissues and pre-B- cell lines using the Trizol reagent (GIBCO-BRL), and 10-20 $\mathrm{\mu g}$ of each RNA preparation were analyzed by RNase protection assay according to Vitelli et al. (1988) except that a hybridization temperature of $60^{\circ} \mathrm{C}$ was used.

\section{Acknowledgments}

We are grateful to $\mathrm{D}$. Fearon for providing cloned mCD19 cDNA and anti-mCD19 mAb, to L. Mårtensson, D. Schatz, S. Desiderio, T. Wirth, M. Reth, and M.D. Walker for providing additional cDNA clones; E. ten Boekel for advice on the single cell PCR analysis; P.G. Graninger for technical assistance; M. King for help with animal experiments; G. Schaffner for oligonucleotide synthesis; I. Botto and R. Kurzbauer for DNA sequencing; and $\mathrm{H}$. Beug and $\mathrm{T}$. Jenuwein for critical reading of the manuscript. This work was financed by the Institute of Molecular Pathology, by a grant from the Austrian Industrial Research Promotion Fund and by the Basel Institute for Immunology that was founded and is supported by F. Hoffmann-LaRoche Ltd., Basel, Switzerland. P.U. was on a leave of absence from the Institute of Molecular Genetics, Academy of Sciences of the Czech Republic, Prague, Czech Republic.

The publication costs of this article were defrayed in part by payment of page charges. This article must therefore be hereby marked "advertisement" in accordance with 18 USC section 1734 solely to indicate this fact.

\section{References}

Adams, B., P. Dörfler, A. Aguzzi, Z. Kozmik, P. Urbánek, I. Maurer-Fogy, and M. Busslinger. 1992. Pax5 encodes the transcription factor BSAP and is expressed in B lymphocytes, the developing CNS, and adult testis. Genes \& Dev. 6: 1589 1607.

Alt, F.W. and D. Baltimore. 1982. Joining of immunoglobulin heavy chain gene segments: Implications from a chromosome with evidence of three D-J $\mathrm{J}_{\mathrm{H}}$ fusions. Proc. Natl. Acad. Sci. 79: 4118-4122.

Bain, G., E.C.R. Maandag, D.J. Izon, D. Amsen, A.M. Kruisbeek, B.C. Weintraub, I. Krop, M.S. Schlissel, A.J. Feeney, M. van Roon, M. van der Valk, H.P.J. te Riele, A. Berns, and C. Murre. 1994. E2A proteins are required for proper B cell development and initiation of immunoglobulin gene rearrangements. Cell 79: 885-892.

Barberis, A., K. Widenhorn, L. Vitelli, and M. Busslinger. 1990. A novel B-cell lineage-specific transcription factor present at early but not late stages of differentiation. Genes \& Dev. 4: 849-859.

Born, W., J. White, J. Kappler, and P. Marrack. 1988. Rearrangement of IgH genes in normal thymocyte development. J. Immunol. 140: 3228-3232.

Busslinger, M. and P. Urbánek. 1995. The role of BSAP (Pax5) in B cell development. Curr. Opin. Genet. Dev. 5: 595-601.

Busslinger, M., N. Klix, P. Pfeffer, P.G. Graninger, and Z. Kozmik. 1996. Deregulation of Pax5 by translocation of the $\mathrm{E} \mu$ enhancer of the IgH locus adjacent to two alternative Pax 5 promoters in a diffuse large-cell lymphoma. Proc. Nat1. Acad. Sci. 93: 6129-6134.

Carter, R.H. and D.T. Fearon. 1992. CD19: Lowering the threshold for antigen receptor stimulation of B lymphocytes. Science 256: 105-107. 
Chang, Y.C., C.J. Paige, and G.E. Wu. 1992. Enumeration and characterization of $\mathrm{DJH}$ structures in mouse fetal liver. EMBO J. 11: 1891-1899.

Chen, J., F. Young, A. Bottaro, V. Stewart, R.K. Smith, and F.W. Alt. 1993. Mutations of the intronic IgH enhancer and its flanking sequences differentially affect accessibility of the $\mathrm{J}_{\mathbf{H}}$ locus. EMBO J. 12: 4635-4645.

Corcoran, L.M., M. Karvelas, G.J.V. Nossal, Z.-S. Ye, T. Jacks, and D. Baltimore. 1993. Oct-2, although not required for early B-cell development, is critical for later B-cell maturation and for postnatal survival. Genes \& Dev. 7: 570-582.

Cory, S., J.M. Adams, and D.J. Kemp. 1980. Somatic rearrangements forming active immunoglobulin $\mu$ genes in $B$ and $T$ lymphoid cell lines. Proc. Nat1. Acad. Sci. 77: 4943-4947.

Czerny, T., G. Schaffner, and M. Busslinger. 1993. DNA sequence recognition by Pax proteins: Bipartite structure of the paired domain and its binding site. Genes \& Dev. 7: 20482061.

Desiderio, S.V., G.D. Yancopoulos, M. Paskind, E. Thomas, M.A. Boss, N. Landau, F.W. Alt, and D. Baltimore. 1984. Insertion of $N$ regions into heavy-chain genes is correlated with expression of terminal deoxynucleotidyl transferase in B cells. Nature 311: 752-755.

Dörfler, P. and M. Busslinger. 1996. C-terminal activating and inhibitory domains determine the transactivation potential of BSAP (Pax5), Pax-2 and Pax-8. EMBO J. 15: 1971-1982.

Dymecki, S.M., J.E. Niederhuber, and S.V. Desiderio. 1990. Specific expression of a tyrosine kinase gene, $b l k$, in B lymphoid cells. Science 247: 332-336.

Ehlich, A., S. Schaal, H. Gu, D. Kitamura, W. Müller, and K. Rajewsky. 1993. Immunoglobulin heavy and light chain genes rearrange independently at early stages of B cell development. Cell 72: 695-704.

Ehlich, A., V. Martin, W. Müller, and K. Rajewsky. 1994. Analysis of the B-cell progenitor compartment at the level of single cells. Curr. Biol. 4: 573-583.

Engel, P., L.-J. Zhou, D.C. Ord, S. Sato, B. Koller, and T.F. Tedder. 1995. Abnormal B lymphocyte development, activation, and differentiation in mice that lack or overexpress the CD19 signal transduction molecule. Immunity 3: 39-50.

Falkner, F.G. and H.G. Zachau. 1984. Correct transcription of an immunoglobulin $\kappa$ gene requires an upstream fragment containing conserved sequence elements. Nature 310: 7174.

Ferrier, P., B. Krippl, T.K. Backwell, A.J.W. Furley, H. Suh, A. Winoto, W.D. Cook, L. Hood, F. Costantini, and F.W. Alt. 1990. Separate elements control DJ and VDJ rearrangement in a transgenic recombination substrate. EMBO I. 9: 117125.

Georgopoulos, K., M. Bigby, J.-H. Wang, A. Molnar, P. Wu, S. Winandy, and A. Sharpe. 1994. The Ikaros gene is required for the development of all lymphoid lineages. Cell 79: 143156.

Gong, S. and M.C. Nussenzweig. 1996. Regulation of an early developmental checkpoint in the B cell pathway by Ig $\beta$. Science 272: 411-414.

Grawunder, U., T.M.J. Leu, D.G. Schatz, A. Werner, A.G. Rolink, F. Melchers, and T.H. Winkler. 1995. Down-regulation of RAG1 and RAG2 gene expression in preB cells after functional immunoglobulin heavy chain rearrangement. Immunity 3: 601-608.

Gu, H., D. Kitamura, and K. Rajewsky. 1991. B cell development regulated by gene rearrangement: Arrest of maturation by membrane-bound $\mathrm{D} \mu$ protein and selection of $\mathrm{D}_{\mathrm{H}}$ element reading frames. Cell 65: 47-54.

Hagman, J. and R. Grosschedl. 1994. Regulation of gene expres- sion at early stages of B-cell differentiation. Curr. Opin. Immunol. 6: 222-230.

Hardy, R.R. and K. Hayakawa. 1994. CD5 B cells, a fetal B cell lineage. Adv. Immunol. 55: 297-339.

Hardy, R.R., C.E. Carmack, S.A. Shinton, J.D. Kemp, and K. Kayakawa. 1991. Resolution and characterization of pro-B and pre-pro-B cell stages in normal mouse bone marrow. $I$. Exp. Med. 173: 1213-1225.

Hayashi, S.-I., T. Kunisada, M. Ogawa, T. Sudo, H. Kodama, T. Suda, S. Nishikawa, and S.-I. Nishikawa. 1990. Stepwise progression of B lineage differentiation supported by interleukin-7 and other stromal cell molecules. I. Exp. Med. 171: 1683-1695.

Hermanson, G.G., D. Eisenberg, P.W. Kincade, and R. Wall. 1988. B29: A member of the immunoglobulin gene superfamily exclusively expressed on B-lineage cells. Proc. Nat1. Acad. Sci. 85: 6890-6894.

Ichihara, Y., H. Hayashida, S. Miyazawa, and Y. Kurosawa. 1989. Only $D_{\mathrm{FL16}}, \mathrm{D}_{\mathrm{SP} 2}$, and $\mathrm{D}_{\mathrm{Q52}}$ gene families exist in mouse immunoglobulin heavy chain diversity gene loci, of which $\mathrm{D}_{\mathrm{FL} 16}$ and $\mathrm{D}_{\mathrm{SP} 2}$ originate from the same primordial $\mathrm{D}_{\mathrm{H}}$ gene. Eur. I. Immunol. 19: 1849-1854.

Kantor, A.B. and L.A. Herzenberg. 1993. Origin of murine B cell lineages. Annu. Rev. Immunol. 11: 501-538.

Kantor, A.B., A.M. Stall, S. Adams, L.A. Herzenberg, and L.A. Herzenberg. 1992. Differential development of progenitor activity for three B-cell lineages. Proc. Natl. Acad. Sci. 89: $3320-3324$.

Karasuyama, H., A. Kudo, and F. Melchers. 1990. The proteins encoded by the $\mathrm{V}_{\text {preB }}$ and $\lambda 5$ pre-B cell-specific genes can associate with each other and with $\mu$ heavy chain. J. Exp. Med. 172: 969-972.

Karasuyama, H., A. Rolink, and F. Melchers. 1993. A complex of glycoproteins is associated with $\mathrm{V}_{\text {preB }} / \lambda 5$ surrogate light chain on the surface of $\mu$ heavy chain-negative early precursor B cell lines. J. Exp. Med. 178: 469-478.

Karasuyama, H., A. Rolink, Y. Shinkai, F. Young, F.W. Alt, and F. Melchers. 1994. The expression of $V_{\text {pre- } \mathrm{B}} / \lambda 5$ surrogate light chain in early bone marrow precursor B cells of normal and B cell-deficient mutant mice. Cell 77: 133-143.

Kim, U., X.-F. Qin, S. Gong, S. Stevens, Y. Luo, M. Nussenzweig, and R.G. Roeder. 1996. The B-cell-specific transcription coactivator OCA-B/OBF-1/Bob-1 is essential for normal production of immunoglobulin isotypes. Nature 383: 542 547.

Kitamura, D. and K. Rajewsky. 1992. Targeted disruption of $\mu$ chain membrane exon causes loss of heavy-chain allelic exclusion. Nature 356: 154-156.

Kitamura, D., J. Roes, R. Kühn, and K. Rajewsky. 1991. A B cell-deficient mouse by targeted disruption of the membrane exon of the immunoglobulin $\mu$ chain gene. Nature 350: 423 426.

Kitamura, D., A. Kudo, S. Schaal, W. Müller, F. Melchers, and K. Rajewsky. 1992. A critical role of $\lambda 5$ protein in B cell development. Cell 69: 823-831.

Kozmik, Z., S. Wang, P. Dörfler, B. Adams, and M. Busslinger. 1992. The promoter of the CD19 gene is a target for the B-cell-specific transcription factor BSAP. Mol. Cell. Biol. 12: $2662-2672$.

Krop, I., A.R. de Fougerolles, R.R. Hardy, M. Allison, M.S. Schlissel, and D.T. Fearon. 1996. Self-renewal of B-1 lymphocytes is dependent on CD19. Eur. J. Immunol. 26: 238-242.

Kudo, A. and F. Melchers. 1987. A second gene, $V_{\text {preB }}$ in the $\lambda 5$ locus of the mouse, which appears to be selectively expressed in pre-B lymphocytes. EMBO I. 6: 2267-2272.

Kudo, A., N. Sakaguchi, and F. Melchers. 1987. Organization of 
the murine Ig-related $\lambda 5$ gene transcribed selectively in pre-B lymphocytes. EMBO \%. 6: 103-107.

Kurosawa, Y., H. von Boehmer, W. Haas, H. Sakano, A. Trauneker, and S. Tonegawa. 1981. Identification of D segments of immunoglobulin heavy-chain genes and their rearrangement in T lymphocytes. Nature 290: 565-570.

Lafaille, J.J., A. DeCloux, M. Bonneville, Y. Takagaki, and S. Tonegawa. 1989. Junctional sequences of T cell receptor $\gamma \delta$ genes: Implications for $\gamma \delta \mathrm{T}$ cell lineages and for a novel intermediate of V-(D)-J joining. Cell 59: 859-870.

Law, C.-L. and E.A. Clark. 1994. Cell-cell interactions that regulate the development of B-lineage cells. Curr. Opin. Immunol. 6: 238-247.

Lennon, G. and R. Perry. 1985. $\mathrm{C}_{\mu}$-containing transcripts initiate heterogeneously within the $I g H$ enhancer region and contain a novel $5^{\prime}$-untranslatable exon. Nature 318: 475478.

Leptin, M., M.J. Potash, R. Grützmann, C. Heusser, M. Shulman, G. Köhler, and F. Melchers. 1984. Monoclonal antibodies specific for murine IgM. I. Characterization of antigenic determinants on the four constant domains of the $\mu$ heavy chain. Eur. J. Immunol. 14: 534-542.

Lewis, S.M. 1994. The mechanism of V(D)I joining: Lessons from molecular, immunological, and comparative analyses. Adv. Immunol. 56: 27-150.

Li, Y.-S., K. Hayakawa, and R.R. Hardy. 1993. The regulated expression of B lineage associated genes during B cell differentiation in bone marrow and fetal liver. I. Exp. Med. 178: 951-960.

Liao, F., B.K. Birshtein, M. Busslinger, and P. Rothman. 1994. The transcription factor BSAP (NF-HB) is essential for immunoglobulin germ-line $\epsilon$ transcription. I. Immunol. 152: 2904-2911.

Lin, H. and R. Grosschedl. 1995. Failure of B-cell differentiation in mice lacking the transcription factor EBF. Nature 376: $263-267$.

Löffert, D., A. Ehlich, W. Müller, and K. Rajewsky. 1996. Surrogate light chain expression is required to establish immunoglobulin heavy chain allelic exclusion during early B cell development. Immunity 4: 133-144.

Malynn, B.A., G.D. Yancopoulos, J.E. Barth, C.A. Bona, and F.W. Alt. 1990. Biased expression of $\mathrm{J}_{\mathrm{H}}$-proximal $\mathrm{V}_{\mathrm{H}}$ genes occurs in the newly generated repertoire of neonatal and adult mice. I. Exp. Med. 171: 843--859.

Mason, J.O., G.T. Williams, and M.S. Neuberger. 1985. Transcription cell type specificity is conferred by an immunoglobulin $\mathrm{V}_{\mathrm{H}}$ gene promoter that includes a functional consensus sequence. Cell 41: 479-487.

Neurath, M.F., W. Strober, and Y. Wakatsuki. 1994. The murine $\operatorname{Ig} 3^{\prime} \alpha$ enhancer is a target site with repressor function for the $\mathrm{B}$ cell lineage-specific transcription factor BSAP (HF-HB, S $\alpha$ BP). I. Immunol. 153: 730-742.

Oettinger, M.A., D.G. Schatz, C. Gorka, and D. Baltimore. 1990. RAG-1 and RAG-2, adjacent genes that synergistically activate $\mathrm{V}(\mathrm{D}) \mathrm{J}$ recombination. Science 248: 1517-1523.

Ogawa, M., S. Nishikawa, K. Ikuta, F. Yamamura, M. Naito, K. Takahashi, and S.-I. Nishikawa. 1988. B cell ontogeny in murine embryo studied by a culture system with the monolayer of a stromal cell clone, ST2: B cell progenitor develops first in embryonal body rather than in yolk sac. $E M B O H$. 7: 1337-1343.

Ogawa, M., Y. Matsuzaki, S. Nishikawa, S.-I. Hayashi, T. Kunisada, T. Sudo, T. Kina, H. Nakauchi, and S.-I. Nishikawa. 1991. Expression and function of c-kit in hematopoietic progenitor cells. J. Exp. Med. 174: 63-71.

Okabe, T., T. Watanabe, and A. Kudo. 1992. A pre-B- and B cell-specific DNA-binding protein, EBB-1, which binds to the promoter of the $\mathrm{V}_{\mathrm{preB}}$ gene. Eur. I. Immunol. 22: 37-43.

Oltz, E.M., G.D. Yancopoulos, M.A. Morrow, A. Rolink, G. Lee, F. Wong, K. Kaplan, S. Gillis, F. Melchers, and F.W. Alt. 1992. A novel regulatory myosin light chain gene distinguishes pre-B cell subsets and is IL-7 inducible. EMBO /. 11: $2759-2767$.

Reimold, A.M., P.D. Ronath, Y.-S. Li, R.R. Hardy, C.S. David, J.L. Strominger, and L.H. Glimcher. 1996. Transcription factor $\mathrm{B}$ cell lineage-specific activator protein regulates the gene for human X-box binding protein 1. I. Exp. Med. 183: 393401.

Rickert, R.C., K. Rajewsky, and J. Roes. 1995. Impairment of T-cell-dependent B-cell responses and B-1 cell development in CD19-deficient mice. Nature 376: 352-355.

Rolink, A. and F. Melchers. 1991. Molecular and cellular origins of B lymphocyte diversity. Cell 66: 1081-1094.

Rolink, A., M. Streb, S.-I. Nishikawa, and F. Melchers. 1991a. The c-kit-encoded tyrosine kinase regulates the proliferation of early pre-B cells. Eur. J. Immunol. 21: 2609-2612.

Rolink, A., A. Kudo, H. Karasuyama, Y. Kikuchi, and F. Melchers. 1991b. Long-term proliferating early pre B cell lines and clones with the potential to develop to surface Ig-positive, mitogen reactive $\mathrm{B}$ cells in vitro and in vivo. EMBO I. 10: 327-336

Rolink, A., D. Haasner, S.-I. Nishikawa, and F. Melchers. 1993. Changes in frequencies of clonable pre-B cells during life in different lymphoid organs of mice. Blood 81: 2290-2300.

Rolink, A., U. Grawunder, T.H. Winkler, H. Karasuyama, and F. Melchers. 1994. IL-2 receptor $\alpha$ chain (CD25,TAC) expression defines a crucial stage in pre-B cell development. Int. Immunol. 6: 1257-1264.

Rolink, A., E. ten Boekel, F. Melchers, D.T. Fearon, I. Krop, and J. Andersson. 1996. A subpopulation of $\mathrm{B}_{220^{+}}$cells in murine bone marrow does not express CD19 and contains natural killer cell progenitors. J. Exp. Med. 183: 187-194.

Roque, M.C., P.A. Smith, and V.C. Blasquez. 1996. A developmentally modulated chromatin structure at the mouse immunoglobulin $\kappa 3^{\prime}$ enhancer. Mol. Cell. Biol. 16: 3138-3155.

Schatz, D.G., M.A. Oettinger, and D. Baltimore. 1989. The V(D)J recombination activating gene, RAG-1. Cell 59: 1035-1048.

Schilham, M.W., M.A. Oosterwegel, P. Moerer, J. Ya, P.A.J. de Boer, M. van de Wetering, S. Verbeek, W.H. Lamers, A.M. Kruisbeek, A. Cumano, and H. Clevers. 1996. Defects in cardiac outflow tract formation and pro-B-lymphocyte expansion in mice lacking Sox-4. Nature 380: 711-714.

Schlissel, M.S. and D. Baltimore. 1989. Activation of immunoglobulin kappa gene rearrangement correlates with induction of germline kappa gene transcription. Cell 58: 10011007.

Schlissel, M., A. Voronova, and D. Baltimore. 1991a. Helixloop-helix transcription factor E47 activates germ-line immunoglobulin heavy-chain gene transcription and rearrangement in a pre-T cell line. Genes \& Dev. 5: 1367-1376.

Schlissel, M.S., L.M. Corcoran, and D. Baltimore. 1991b. Virustransformed pre-B cells show ordered activation but not inactivation of immunoglobulin gene rearrangement and transcription. J. Exp. Med. 173: 711-720.

Schubart, D.B., A. Rolink, M.H. Kosco-Vilbois, F. Botteri, and P. Matthias. 1996. B-cell-specific coactivator OBF-1/OCA-B/ Bob1 required for immune response and germinal centre formation. Nature 383: 538-542.

Scott, E.W., M.C. Simon, J. Anastasi, and H. Singh. 1994. Requirement of transcription factor PU.1 in the development of multiple hematopoietic lineages. Science 265: 1573-1577.

Serwe, M. and F. Sablitzky. 1993. V(D)J recombination in B cells 
is impaired but not blocked by targeted deletion of the immunoglobulin heavy chain intron enhancer. EMBO $I$. 12: 2321-2327.

Sha, W.C., H.-C. Liou, E.I. Tuomanen, and D. Baltimore. 1995. Targeted disruption of the p50 subunit of NF-кB leads to multifocal defects in immune responses. Cell 80: 321330 .

Singh, M. and B.K. Birshtein. 1993. NF-HB (BSAP) is a repressor of the murine immunoglobulin heavy-chain $3^{\prime} \alpha$ enhancer at early stages of B cell differentiation. Mol. Cell. Biol. 13: 3611-3622.

Spanopoulou, E., C.A.J. Roman, L.M. Corcoran, M.S. Schlissel, D.P. Silver, D. Nemazee, M.C. Nussenzweig, S.A. Shinton, R.R. Hardy, and D. Baltimore. 1994. Functional immunoglobulin transgenes guide ordered B-cell differentiation in Rag-1-deficient mice. Genes \& Dev. 8: 1030-1042.

Stuart, E.T., C. Kioussi, and P. Gruss. 1994. Mammalian PAX genes. Annu. Rev. Genet. 28: 219-236.

Sturm, R.A., G. Das, and W. Herr. 1988. The ubiquitous octamer-binding protein Oct-1 contains a POU domain with a homeo box subdomain. Genes \& Dev. 2: 1582-1599.

Sudo, T., S. Nishikawa, N. Ohno, N. Akiyama, M. Tamakoshi, H. Yoshida, and S.-I. Nishikawa. 1993. Expression and function of the interleukin 7 receptor in murine lymphocytes. Proc. Natl. Acad. Sci. 90: 9125-9129.

Takeda, S., Y.-R. Zou, H. Bluethmann, D. Kitamura, U. Müller, and K. Rajewsky. 1993. Deletion of the immunoglobulin $\kappa$ chain intron enhancer abolishes $\kappa$ chain gene rearrangement in cis but not $\lambda$ chain gene rearrangement in trans. EMBO $J$. 12: 2329-2336.

ten Boekel, E., F. Melchers, and A. Rolink. 1995. The status of Ig loci rearrangements in single cells from different stages of B cell development. Int. Immunol. 7: 1013-1019.

Tsubata, T. and M. Reth. 1990. The products of the pre-B cellspecific genes $\left(\lambda 5\right.$ and $\left.V_{\text {preB }}\right)$ and the immunoglobulin $\mu$ chain form a complex that is transported onto the cell surface. J. Exp. Med. 172: 973-976.

Urbánek, P., Z.-Q. Wang, I. Fetka, E.F. Wagner, and M. Busslinger. 1994. Complete block of early B cell differentiation and altered patterning of the posterior midbrain in mice lacking Pax5/BSAP. Cell 79: 901-912.

Vitelli, L., I. Kemler, B. Lauber, M.L. Birnstiel, and M. Busslinger. 1988. Developmental regulation of micro-injected histone genes in sea urchin embryos. Dev. Biol. 127: 54-63.

Wakatsuki, Y.W., M.F. Neurath, E.E. Max, and W. Strober. 1994. The B cell-specific transcription factor BSAP regulates B cell proliferation. I. Exp. Med. 179: 1099-1108.

Walker, M.D., C.W. Park, A. Rosen, and A. Aronheim. 1990. A cDNA from a mouse pancreatic $\beta$ cell encoding a putative transcription factor of the insulin gene. Nucleic Acids Res. 18: 1159-1166.

Wallin, J., H. Eibel, A. Neubüser, J. Wilting, H. Koseki, and R. Balling. 1996. Pax1 is expressed during development of the thymus epithelium and is required for normal T-cell maturation. Development 122: 23-30.

Winkler, T.H., A. Rolink, F. Melchers, and H. Karasuyama. 1995. Precursor B cells of mouse bone marrow express two different complexes with the surrogate light chain on the surface. Eur. J. Immunol. 25: 446-450.

Wirth, T., A. Priess, A. Annweiler, S. Zwilling, and B. Oeler. 1991. Multiple Oct 2 isoforms are generated by alternative splicing. Nucleic Acids Res. 19: 43-51.

Yancopoulos, G.D. and F.W. Alt. 1985. Developmentally controlled and tissue-specific expression of unrearranged $\mathrm{V}_{\mathrm{H}}$ gene segments. Cell 40: 271-281.

Yancopoulos, G.D., B.A. Malynn, and F.W. Alt. 1988. Develop- mentally regulated and strain-specific expression of murine $\mathrm{V}_{\mathrm{H}}$ gene families. J. Exp. Med. 168: 417-435.

Young, F., B. Ardman, Y. Shinkai, R. Landford, T.K. Blackwell, M. Mendelsohn, A. Rolink, F. Melchers, and F.W. Alt. 1994. Influence of immunoglobulin heavy- and light-chain expression on B-cell differentiation. Genes \& Dev. 8: 1043-1057.

Zhuang, Y., P. Soriano, and H. Weintraub. 1994. The helix-loophelix gene E2A is required for B cell formation. Cell 79: 875884.

Zwollo, P. and S. Desiderio. 1994. Specific recognition of the blk promoter by the B-lymphoid transcription factor B-cell-specific activator protein. J. Biol. Chem. 269: 15310-15317. 


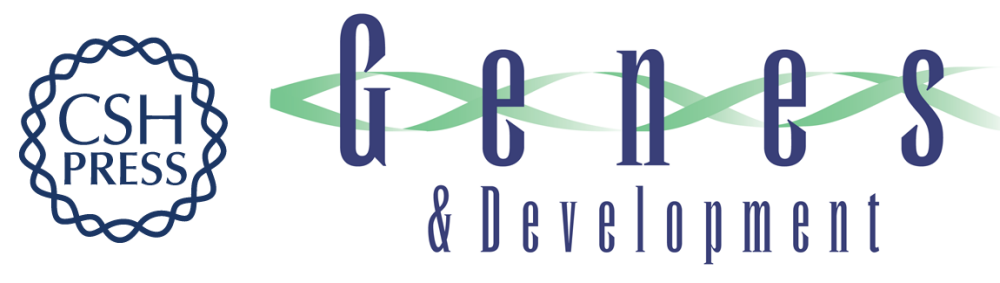

\section{Essential functions of Pax5 (BSAP) in pro-B cell development: difference between fetal and adult $B$ lymphopoiesis and reduced V-to-DJ recombination at the IgH locus.}

S L Nutt, P Urbánek, A Rolink, et al.

Genes Dev. 1997, 11:

Access the most recent version at doi:10.1101/gad.11.4.476

References This article cites 100 articles, 41 of which can be accessed free at: http://genesdev.cshlp.org/content/11/4/476.full.html\#ref-list-1

License

Email Alerting Receive free email alerts when new articles cite this article - sign up in the box at the top Service right corner of the article or click here.

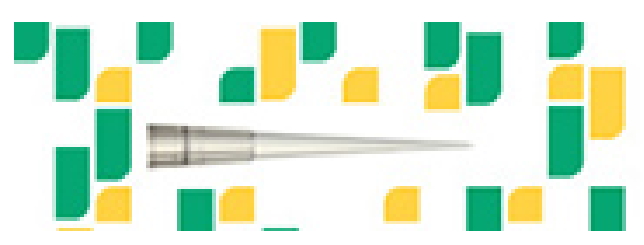

Focused on your science. 